\title{
Enhanced Tumor Targeting and Antitumor Activity of Gemcitabine Encapsulated Stealth Liposome's
}

\author{
Ganesh Sheshrao Bangale ${ }^{* 1}$, Rajesh Kesarala ${ }^{2}$ and Gajanan Vishwambharao Shinde ${ }^{2}$ \\ 1Department of Pharmaceutics, Government College of Pharmacy, Amravati (M.S.),INDIA. \\ ${ }^{2}$ Department of Pharmaceutics, Parul Institute of Pharmacy, Vadodara, Gujarat. INDIA.
}

\begin{abstract}
Introduction: Cancer is a term used for diseases in which abnormal cells divide without control and are able to invade other tissues. Gemcitabine is new cytotoxic drug but some of limitations while its use likes it suppress the activity of Bone marrow i.e. effect on blood forming cells, lower half life-7-18 min.unable to deliver by oral \& other route. Higher dose-1000-1250 mg/m2 require against malignancies. Effective against various solid tumor like colon, lungs, breast etc. Several attempt was made to enhance efficacy of gemcitabine against tumor including novel stealth liposomal technology might proves to avoids above limitation. Method: A present investigation focuses on to enhance encapsulation of gemcitabine inside the vesicle by adopting $\mathrm{pH}$ gradient methods followed by solvent evaporation. The resulting formulation of liposomes are characterize by vesicle size, zeta potential by zeta sizer along with encapsulation efficiency by centrifugation. The optimization of formulation was carried out by statistically by 32 factorial design. The optimized formulation further subjected for in vitro antitumor activity i.e. cell line study and in vivo performance by using animal model. Results: The stealth liposomal formulation comparatively evaluated with conventional liposomes and pure drug based on cell line study proves that stealth liposomes are effectively retarding the \% tumor cell growth than others. Bio distribution profile of stealth liposomes in various organs assure for prolong circulation half of formulation and maximum tumor concentration of drug even after $24 \mathrm{hrs}$ study. There is no sign of toxicity after administration supported by data obtained through toxicity studies. Conclusion: The final outcomes of research was antitumor activity of gemcitabine improved by PEGylation (stealth) technology which also minimize unwanted toxicities associated with gemcitabine via other route of administration.
\end{abstract}

Key words: Gemcitabine, Pharmacokinetic, pH gradient, Stealths Liposome, Zeta potential.

\section{INTRODUCTION}

Cancer is a term used for diseases in which abnormal cells divide without control and are able to invade other tissues. Cancer cells can spread to other parts of the body through the blood and lymph systems. Cancer is not just one disease but many diseases. There are more than 200 different types of cancer. ${ }^{1-4}$ For instance, although there are numerous anticancer agents that are highly cytotoxic to tumor cells in vitro, the lack of selective antitumor effect in vivo precludes their use in clinic. One of the major limitations of antineoplastic drugs is their low therapeutic index (TI), i.e. the dose required to produce anti-tumor effect is toxic to normal tissues. ${ }^{5}$
Liposomes are spherical vesicles composed of lipid bilayers arranged around a central aqueous core. The particle size of liposomes ranges from $20 \mathrm{~nm}$ to $10 \mu \mathrm{m}$ in diameter. They can be composed of natural constituents such as phospholipids and may mimic naturally occurring cell membranes. Liposomes have the ability to incorporate lipophilic and hydrophilic drugs within their phospholipid membrane or they can encapsulate hydrophilic compounds within the aqueous core. $^{6}$

Gemcitabine is new cytotoxic drug but some limitations restrict its use, for example it suppress the activity of Bone marrow i.e. effect on blood forming cells. Higher water
Submission Date : 16-12-2014 Revision Date : :16-03-2015 Accepted Date : :23-04-2015

DOI: $10.5530 /$ ijper.49.4.8 Correspondence Address Mr. Ganesh S. Bangale Assistant Professor, Department of Pharmaceutics

Government College of Pharmacy

Amravati, Maharashtra, India. Email: gsbangale@yahoo. co.in

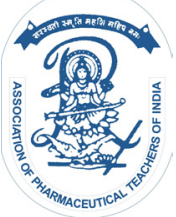

www.ijper.org 


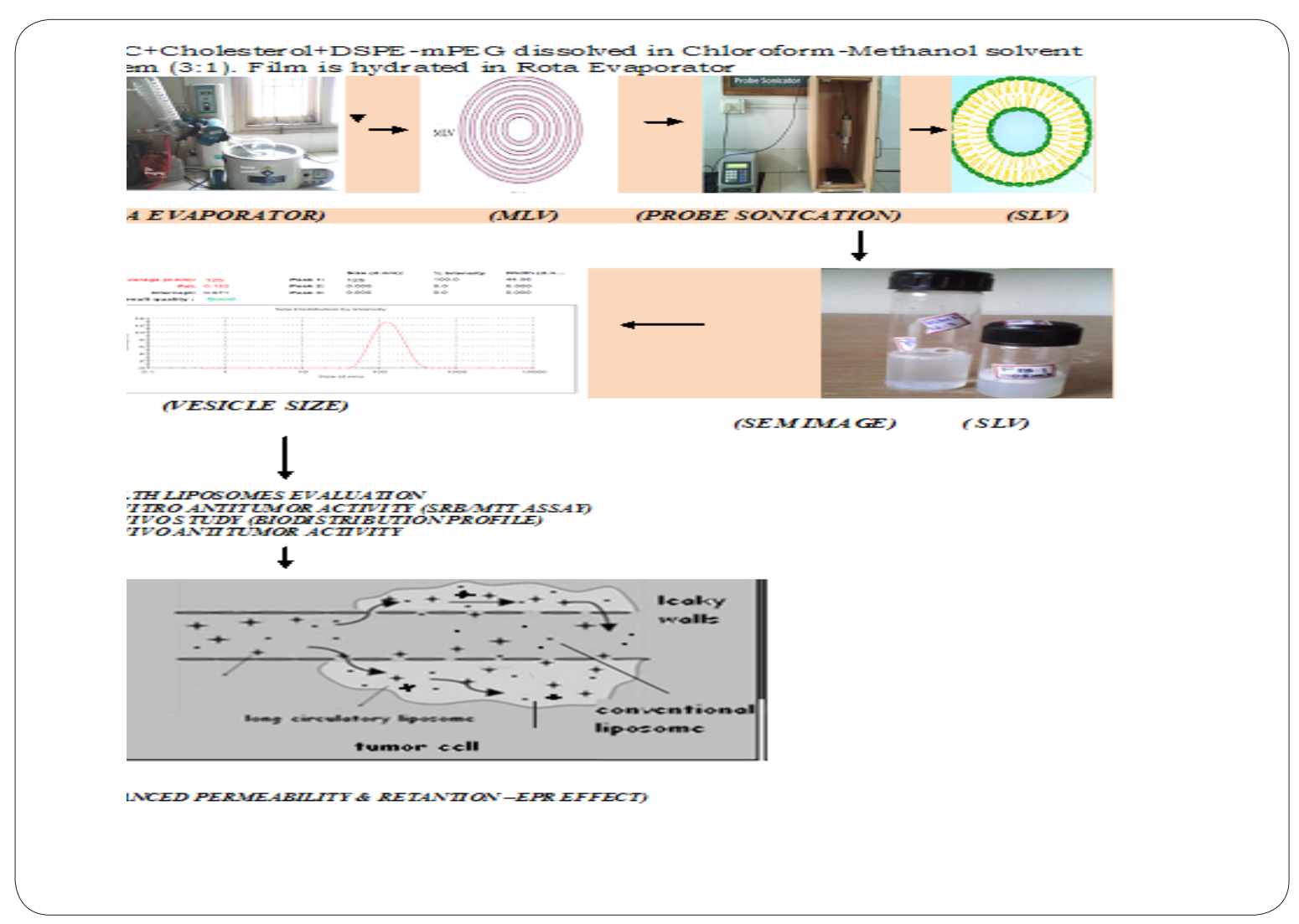

\section{Pictorial Abstract}

solubility needs to improve encapsulation efficiency for better therapeutics effect. (Stealth liposomes by $\mathrm{pH}$ gradient technology), lower half life- 7-18 min. unable to deliver by oral and other route. Higher dose-1000-1250 $\mathrm{mg} / \mathrm{m}^{2}$ require against malignancies. Effective against various solid tumors like colon, lungs, breast etc., ${ }^{7,8}$ Sterically stabilized liposomes can be formulated by incorporating hydrophilic long-chain polymers (PEG) in the bilayer which can form a coat on the liposome surface and repel opsonin penetration and adsorption. Reduction in 'marking' by opsonins leads to slower uptake of these liposomes (LCL) by the cells of reticuloendothelial system (RES).' The present investigation focuses on to perform innovative research work to avoid the problem associated with gemcitabine use and effective against solid tumor with minimum toxic effect by incorporating it in stealth liposomes.

\section{MATERIALS AND METHODS}

Gemcitabine was obtained as gift sample from Sun Pharma Pvt Ltd, Vadodara, (DPPC) 1,2-Dipalmitoyl-sn-glycero-3-phosphocholine, Syoa PC, (DSPE-MPEG-2000) 1,2-Distearoyl-sn-glycero3-phosphoethanolamine-methyl-polyethyleneglycol conjugate- $2000 \mathrm{Na}^{+}$salt, Cholesterol was obtained from Lipoid GmbH, Ludwigshafen, Germany, Chloroform, Methanol, and other chemical was purchased from Loba Chemicals, Mumbai. All other solvent and reagents were of analytical grade.

\begin{tabular}{|c|c|c|c|c|c|c|c|c|}
\hline \multicolumn{7}{|c|}{ Table 1: Composition of Conventional Liposomes } \\
\hline Batch Code & $\begin{array}{c}\text { Gem } \\
\text { Citabine } \\
\text { (mg) }\end{array}$ & $\begin{array}{c}\text { Soya PC } \\
\text { (Molar } \\
\text { Conc.) }\end{array}$ & $\begin{array}{c}\text { DPPC } \\
\text { (Molar } \\
\text { Conc.) }\end{array}$ & $\begin{array}{c}\text { Cholesterol } \\
\text { (Molar } \\
\text { Conc.) }\end{array}$ & $\begin{array}{c}\text { Chloroform } \\
\text { (ml) }\end{array}$ & $\begin{array}{c}\text { Methanol } \\
\text { (ml) }\end{array}$ & $\begin{array}{c}\text { Distil } \\
\text { Water } \\
\text { (ml) }\end{array}$ & $\begin{array}{c}\text { Drug : } \\
\text { Lipid } \\
\text { Ratio }\end{array}$ \\
\hline CL-1 & 10 & 5 & --- & 1 & 5 & 5 & 10 & $1: 6$ \\
\hline CL-2 & 10 & 6 & --- & 2 & 5 & 5 & 10 & $1: 8$ \\
\hline CL-3 & 10 & 7 & --- & 3 & 5 & 5 & 10 & $1: 10$ \\
\hline CL-4 & 10 & --- & 5 & 1 & 5 & 5 & 10 & $1: 6$ \\
\hline CL-5 & 10 & --- & 6 & 2 & 5 & 5 & 10 & $1: 8$ \\
\hline CL-6 & 10 & --- & 7 & 3 & 5 & 5 & 10 & $1: 10$ \\
\hline
\end{tabular}




\begin{tabular}{|c|c|c|c|c|c|c|c|c|c|}
\hline \multicolumn{7}{|c|}{ Table 2: Composition of Stealth Liposomes } \\
\hline $\begin{array}{c}\text { Batch } \\
\text { Code }\end{array}$ & $\begin{array}{c}\text { Gemcitabine } \\
\text { (mg) }\end{array}$ & $\begin{array}{c}\text { Soya PC } \\
\text { (Molar } \\
\text { Conc.) }\end{array}$ & $\begin{array}{c}\text { DPPC } \\
\text { (Molar } \\
\text { Conc.) }\end{array}$ & $\begin{array}{c}\text { DSPE- } \\
\text { MPEG } \\
\text { (Molar } \\
\text { Conc.) }\end{array}$ & $\begin{array}{c}\text { Cholesterol } \\
\text { (Molar } \\
\text { Conc.) }\end{array}$ & $\begin{array}{c}\text { Chloroform } \\
\text { (ml) }\end{array}$ & $\begin{array}{c}\text { Methanol } \\
\text { (ml) }\end{array}$ & $\begin{array}{c}\text { Distil } \\
\text { Water } \\
(\mathbf{m l})\end{array}$ & $\begin{array}{c}\text { Drug: } \\
\text { Lipid } \\
\text { Ratio }\end{array}$ \\
\hline SL-1 & 10 & 5 & --- & 0.1 & 1 & 5 & 5 & 10 & $1: 6.1$ \\
\hline SL-2 & 10 & 6 & --- & 0.2 & 2 & 5 & 5 & 10 & $1: 7.2$ \\
\hline SL-3 & 10 & 7 & --- & 0.3 & 3 & 5 & 5 & 10 & $1: 10.3$ \\
\hline SL-4 & 10 & --- & 5 & 0.1 & 1 & 5 & 5 & 10 & $1: 6.1$ \\
\hline SL-5 & 10 & --- & 6 & 0.2 & 2 & 5 & 5 & 10 & $1: 7.2$ \\
\hline SL-6 & 10 & --- & 7 & 0.3 & 3 & 5 & 5 & 10 & $1: 10.3$ \\
\hline
\end{tabular}

\begin{tabular}{|c|c|c|c|c|c|}
\hline \multicolumn{5}{|c|}{ Table 3: \% Entrapment Efficiency of Liposomal Formulation } \\
\hline \multirow{2}{*}{$\begin{array}{c}\text { Batch } \\
\text { code }\end{array}$} & $\begin{array}{c}\text { Molar } \\
\text { Conc. of } \\
\text { Soya PC }\end{array}$ & $\begin{array}{c}\text { Molar } \\
\text { Conc. of } \\
\text { DPPC }\end{array}$ & $\begin{array}{c}\text { Molar Conc. of } \\
\text { DSPE-MPEG } \\
\text { 2K }\end{array}$ & $\begin{array}{c}\text { Molar } \\
\text { Conc. of } \\
\text { Cholesterol }\end{array}$ & $\begin{array}{c}\text { pH EE } \\
\text { method }\end{array}$ \\
\hline CL-1 & 5 & -- & -- & 1 & $50 \pm 0.98$ \\
\hline CL-2 & 6 & -- & -- & 2 & $55.0 \pm 4.1$ \\
\hline CL-3 & 7 & -- & -- & 3 & $47.4 \pm 3.2$ \\
\hline CL-4 & -- & 1 & -- & 1 & $63.8 \pm 2.30$ \\
\hline CL-5 & -- & 2 & -- & 2 & $66.5 \pm 1.72$ \\
\hline CL-6 & -- & 3 & -- & 3 & $62.4 \pm 4.31$ \\
\hline SL-1 & 5 & -- & 0.1 & 1 & $66.0 \pm 2.34$ \\
\hline SL-2 & 6 & -- & 0.2 & 2 & $63.5 \pm 5.11$ \\
\hline SL-3 & 7 & -- & 0.3 & 3 & $60.4 \pm 4.13$ \\
\hline SL-4 & -- & 5 & 0.1 & 1 & $70.2 \pm 2.12$ \\
\hline SL-5 & -- & 6 & 0.2 & 2 & $75.3 \pm 4.11$ \\
\hline SL-6 & -- & 7 & 0.3 & 3 & $65.3 \pm 5.41$ \\
\hline
\end{tabular}

\section{Preparation of CL and SL by pH Gradient Method}

Both CL and SL are composed with lipid and cholesterol with different molar ratio is shown in Table 1 and 2.

DPPC: Cholesterol were taken in different molar ratios and dissolved in Chloroform-Methanol solvent system (3:1). Film is hydrated in Rota Evaporator (Equitron Roteva) at controlled pressure, $60 \mathrm{rpm}, 60^{\circ} \mathrm{C}$ under nitrogen purging. Film was formed. Film was kept overnight under vaccum to remove any trace solvents. Hydration of film is done by $(250 \mathrm{mM})$ of Ammonium sulphate solution for 15 min. to establish $\mathrm{pH}$ gradient inside and outside the vesicle to promote encapsulation of hydrophilic drug like gemcitabine. Multi Lamellar Vesicles (MLV) were formed then submitted for 5 cycle ( 3 min each) of Freezing and Thawing at $30^{\circ} \mathrm{C}$ in water bath. Untapped ammonium sulphate was removed by centrifugation (lab centrifuge- Sigma 3, K 30) at 14000 $\mathrm{rpm}$ for $30 \mathrm{~min}$. Pellet is resuspended in an isotonic solution of Gemcitabine at room temp for $3 \mathrm{hrs}$. This will be subjected to Probe sonication (Sonics Vibra cell) for 5 minutes ( 15 seconds sonic on, 5 seconds off) at 20 $\mathrm{kHz}$ at $4^{\circ} \mathrm{C}$. MLV will get converted to Small Unilamel- lar vesicles. Mannitol was dissolved in the solution (30 to $40 \mathrm{mg}$ per $\mathrm{ml}$ of solution) and subjected for Freeze drying. A dry solid powder of the product will finally be obtained at end of lyophilization which can be reconstituted with sterile water for injection and infused. Stealth liposomes were prepared similarly by use of additional lipid such as DSPE-MPEG-2K and process is similar mentioned above. ${ }^{10,11}$

\section{Evaluation of Liposomes}

\section{Entrapment Efficiency ${ }^{12}$}

Gemcitabine entrapped within the liposomes was estimated after removing the unentrapped drug by centrifugation at $10,000 \mathrm{rpm}$ in refrigerated centrifuge. Supernatant contains unentraped free drug which is analyzed by UV Spectroscopy at $268 \mathrm{~nm}$. The pellet formed will be lysed by $1 \mathrm{ml}$ of methanol:ether (50:50 $\mathrm{v} / \mathrm{v})$. This solution is than diluted and analyzed in UV Spectroscopy. The values obtained were same.

$$
\% \mathrm{EE}=1-\frac{\text { Unentrapped drug }}{\text { Entrapped drug }} \times 100
$$




\begin{tabular}{|c|c|c|c|}
\hline \multicolumn{4}{|c|}{ Table 4: Vesicle Size, PDI and Zeta Potential of Con- } \\
ventional Liposomes \\
\hline $\begin{array}{c}\text { Batch } \\
\text { code }\end{array}$ & $\begin{array}{c}\text { Vesicle size } \\
(\mathbf{n m})\end{array}$ & PDI & $\begin{array}{c}\text { Zeta Potential } \\
\text { (mv) }\end{array}$ \\
\hline CL-1 & $209 \pm 1.2$ & 0.49 & -9.3 \\
\hline CL-2 & $265.2 \pm 2.4$ & 0.37 & -10.3 \\
\hline CL-3 & $168.9 \pm 2.1$ & 0.16 & -10.9 \\
\hline CL-4 & $132.5 \pm 0.170$ & 0.21 & -16.3 \\
\hline CL-5 & $145.5 \pm 1.33$ & 0.21 & -30.6 \\
\hline CL-6 & $140.2 \pm 1.98$ & 0.36 & -32.5 \\
\hline
\end{tabular}

\section{Vesicle Size and Size Distribution (PDI) ${ }^{13}$}

The mean particle size and particle size distribution of the trial batch was obtained by Zeta sizer $1 \mathrm{~mL}$ of liposome suspension was diluted to 100 times with the deionized water. The sample was analyzed using Zeta sizer (Nano ZS, Malvern).

\section{Zeta Potentia/14}

Zeta potential of formulation was determined using Zetasizer (Nano ZS, Malvern). $1 \mathrm{~mL}$ of liposome suspension was diluted up to $100 \mathrm{ml}$ using deionised water and sample was placed placed in clear zeta cells and results were recorded. Before putting the fresh sample, cuvettes were washed with the deionised water and rinsed using the sample to be measured before each experiment.

\section{In vitro Release Study ${ }^{15,16}$}

Sigma dialysis membrane (Molecular weight cut-off of $10,000)$ was hydrated with the receptor medium $(\mathrm{pH}$ 7.4 phosphate buffer) for $12 \mathrm{~h}$ before being fastened between the donor and receptor compartments. The diffusion cell apparatus consists of a glass tube with an inner diameter of $2.5 \mathrm{~cm}$, open at both ends, one end of the tube is tied with Sigma dialysis membrane. Liposome equivalent to $10 \mathrm{mg}$ of Gemcitabine was taken in a dialysis tube and placed in $100 \mathrm{ml}$ of PBS (pH 7.4) The medium was stirred by using the magnetic stirrer at 150 $\mathrm{rpm}$ and the temperature was maintained at $35 \pm 0.5^{\circ} \mathrm{C}$ Periodically $5 \mathrm{ml}$ of samples were withdrawn and after

\section{Table 5: Vesicle Size, PDI and Zeta Potential of} Stealth Liposomes

\begin{tabular}{|c|c|c|c|}
\hline $\begin{array}{c}\text { Batch } \\
\text { code }\end{array}$ & $\begin{array}{c}\text { Vesicle size } \\
(\mathbf{n m})\end{array}$ & PDI & Zeta Potential (mv) \\
\hline SL-1 & $155 \pm 4.12$ & 0.26 & -17.4 \\
\hline SL-2 & $145 \pm 3.78$ & 0.52 & -24.7 \\
\hline SL-3 & $150 \pm 3.12$ & 0.22 & -25.0 \\
\hline SL-4 & $145 \pm 2.5$ & 0.347 & -25.3 \\
\hline SL-5 & $130.6 \pm 1.41$ & 0.21 & -35.8 \\
\hline SL-6 & $130 \pm 1$ & 0.12 & -37.3 \\
\hline
\end{tabular}

each withdrawn same volume of medium was placed. All samples were analyzed for Gemcitabine content at 268 $\mathrm{nm}$. The experiment was done in triplicate for $24-48 \mathrm{hr}$.

In vivo Study: (Optimized Conventional and Stealth Liposomes)

\section{Pharmacokinetic Studies ${ }^{17,18}$}

Pharmacokinetic studies were performed using either sex mice (100-200 g). The protocol in prescribed proforma $\mathrm{B}$ for animal studies was submitted to IAFC of Parul institute of pharmacy, Vadodara. Albino mice of either sex were fasted overnight and divided into four groups each containing three mice. The group under treatment was designed as follows

Group I: Tumor control

Group II: Pure gemcitabine

Group III: Conventional liposomes

Group IV: Stealth liposomes

The group I received normal saline buffer solution through tail vein of mice similarly group II, III, IV also received $10 \mathrm{mg} / \mathrm{kg}$ dose of pure drug solution in saline buffer, conventional liposomes, stealth liposomes respectively after 7 days of tumor implantation (MCF-7) when solid tumor sufficiently grows with specific volume. The blood sample were withdrawn at an interval 1, 6, 12, 24 and $48 \mathrm{hrs}$. Distribution profile of gemcitabine in the various organs including plasma were measured by HPLC analysis in which stationary phase C18G (250

\begin{tabular}{|c|c|c|c|c|}
\hline \multicolumn{4}{|c|}{ Table 6: Comparative Pharmacokinetic profile of Pure Gem, CL-5 and SL-5 } \\
\hline $\begin{array}{c}\text { Pharmacokinetic } \\
\text { parameters }\end{array}$ & Units & Free Gemcitabine & $\begin{array}{c}\text { Conventional } \\
\text { liposomes (CL-5) }\end{array}$ & $\begin{array}{c}\text { Stealth liposomes } \\
\text { (SL-5) }\end{array}$ \\
\hline AUC & $\mu \mathrm{g} / \mathrm{ml} \mathrm{h}$ & $8.37 \pm 0.04$ & $15.22 \pm 0.02$ & $19.37 \pm 0.09$ \\
\hline AUMC & $\mu \mathrm{g} / \mathrm{ml} \mathrm{h}$ & $9.65 \pm 0.12$ & $62.55 \pm 0.13$ & $230 \pm 0.11$ \\
\hline $\mathbf{C}_{\max }$ & $\mu \mathrm{g} / \mathrm{ml}$ & $18.8 \pm 0.98$ & $23.3 \pm 2.1$ & $36.2 \pm 1.85$ \\
\hline $\mathbf{V}_{\mathrm{d}}$ & $\mathrm{ml}$ & $5.24 \pm 0.29$ & $3.1 \pm 0.17$ & $2.4 \pm 0.24$ \\
\hline $\mathbf{t}_{1 / 2}$ & $\mathrm{H}$ & $1.33 \pm 0.27$ & $5.28 \pm 1.62$ & $11.48 \pm 0.21$ \\
\hline $\mathbf{K}_{\mathrm{e}}$ & $\mathrm{h}-1$ & $0.11 \pm 0.01$ & $0.33 \pm 0.02$ & $0.01 \pm 0.025$ \\
\hline $\mathrm{Cl}$ & $\mathrm{ml} / \mathrm{min}$ & $2.173 \pm 0.05$ & $0.66 \pm 0.86$ & $0.012 \pm 0.11$ \\
\hline MRT & $\mathrm{H}$ & $1.02 \pm 0.11$ & $4.15 \pm 1.0$ & $12.10 \pm 0.44$ \\
\hline
\end{tabular}




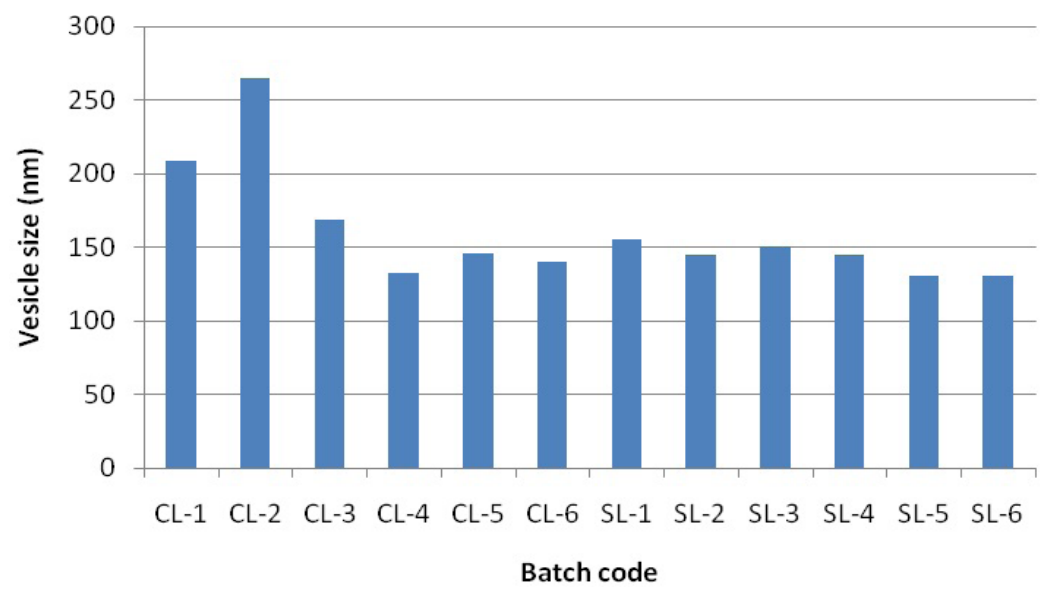

Figure 1: Comparative Vesicle Size (nm) of CL and SL

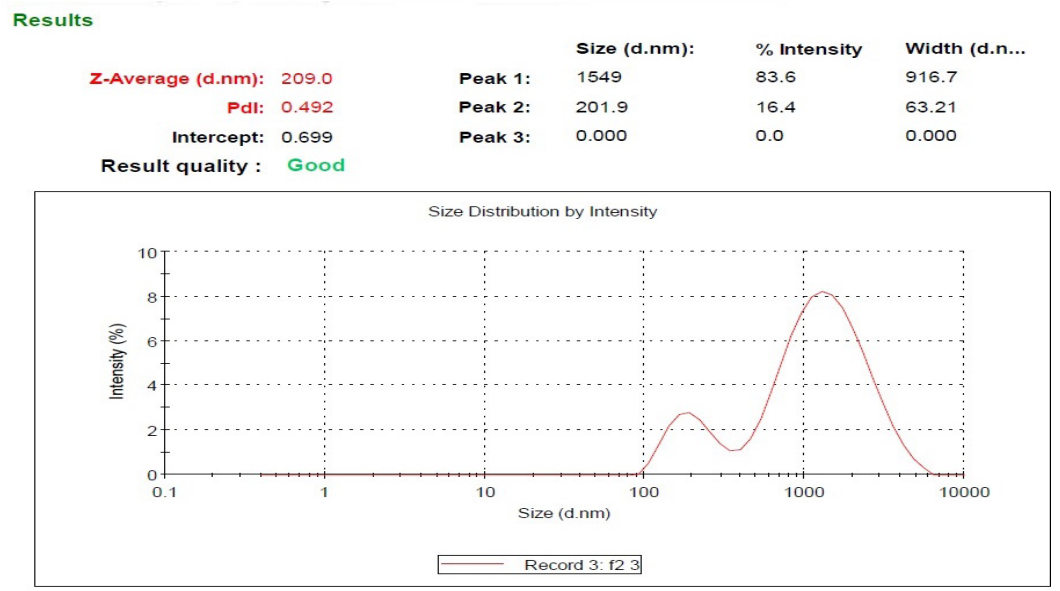

Figure 2: Vesicle size of CL-1

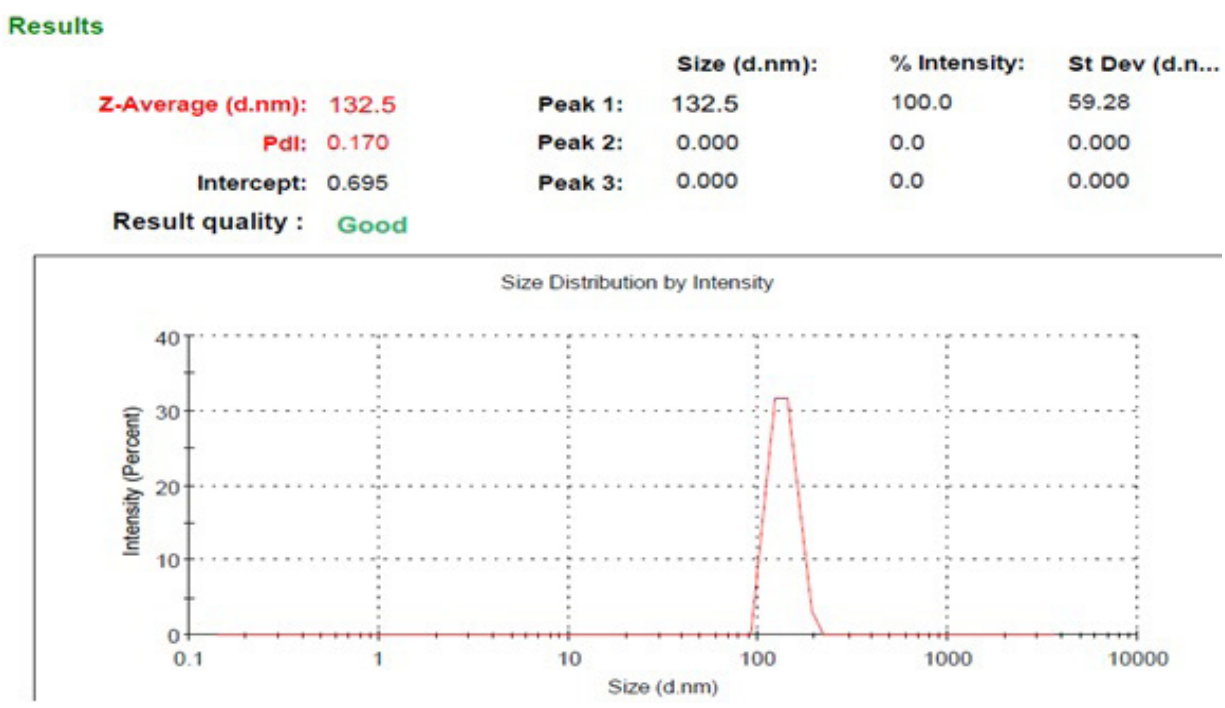

Figure 3: Vesicle size of CL-4

$\times 4.6 \mathrm{~mm}, 5 \mu \mathrm{m})$ and mobile phase was Acetonitrile: methanol (55:45) with flow-rate: $1.0 \mathrm{ml} / \mathrm{min}$, Injection volume: $20 \mu \mathrm{L}$ and detection wavelength were $268 \mathrm{~nm}$. Estimation of gemcitabine was carried out using standard curve and solution was injected and the chromatogram was recorded.

\section{Tissue Distribution Study ${ }^{19,20}$}

To assessment of distribution pattern of gemcitabine in biological organs which assure for either localization of drug towards desired tumor site via prolong circulation or its uptake by RES rich organs like spleen, liver which 


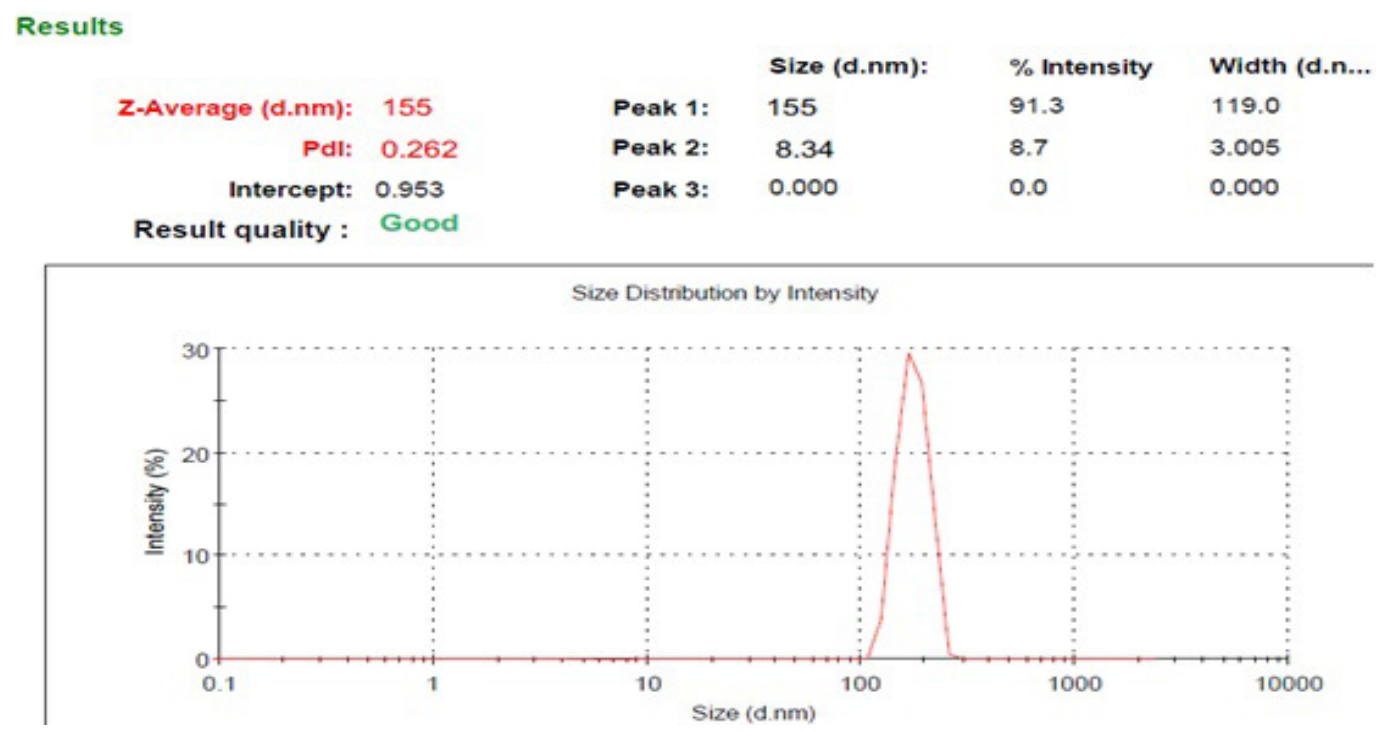

Figure 4: Vesicle size of SL-1

Results

$\begin{array}{rlllll} & & & \text { Size (d.nm): } & \% \text { Intensity } & \text { Width (d.n... } \\ \text { Z-Average (d.nm): } & 145 & \text { Peak 1: } & 150 & 100.0 & 93.30 \\ \text { Pdl: } & 0.347 & \text { Peak 2: } & 0.000 & 0.0 & 0.000 \\ \text { Intercept: } & 1.05 & \text { Peak 3: } & 0.000 & 0.0 & 0.000 \\ \text { Result quality : } & \text { Refer to quality report } & & & \end{array}$

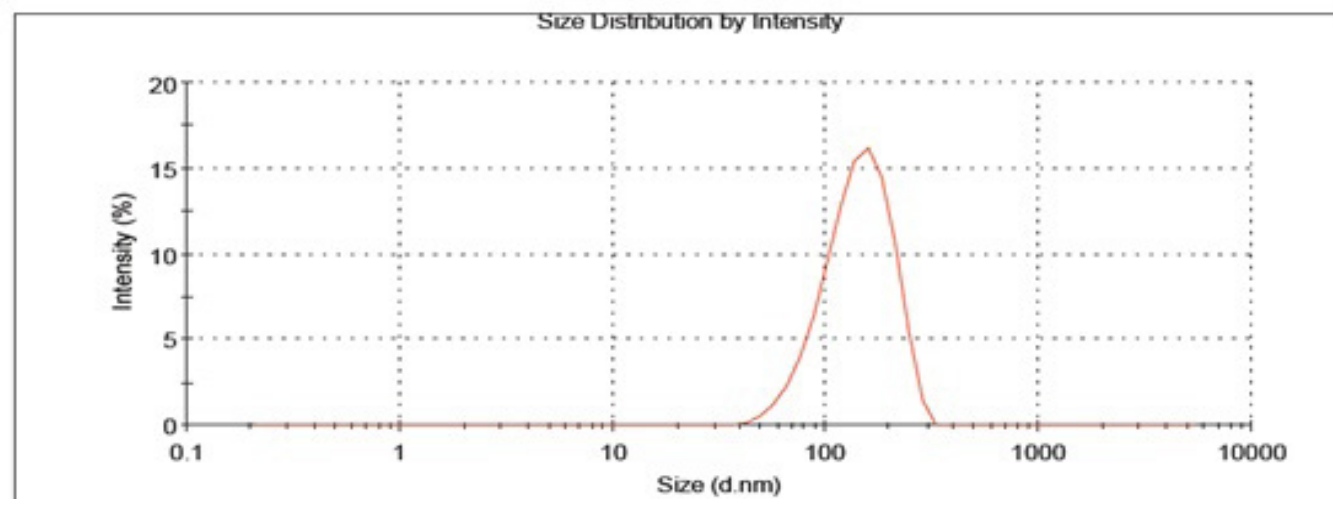

Figure 5: Vesicle size of SL-4

prevent the desire localization hence distribution profile of gemcitabine containing both conventional and stealth liposomes were check out by using tumor bearing animal model. Experiment were carried in similar manner like pharmacokinetic section by receiving out by $10 \mathrm{mg} / \mathrm{kg}$ dose of pure drug solution in saline buffer, conventional liposomes, stealth liposomes respectively after 7 days of tumor implantation when solid tumor sufficiently grows with specific volume. The mice were sacrificed and major organs like lungs, spleen, liver, kidney, tumor were removed, washed with normal saline solution and subjected for centrifugation at $25000 \mathrm{rpm}$ for $10 \mathrm{~min}$. The aliquots were analyzed by HPLC to estimate gemcitabine content in various organs with respect to the time by using standard curve of gemcitabine.

\section{In vivo Antitumor Activity}

The anticancer activity of gemcitabine was evaluated by measuring its cytotoxic effect on tumor by measuring its dimension in suitable animal model based on Tumor volume and Weight parameter.

\section{Effect on Solid Tumor Volume ${ }^{21}$}

The human breast cancer cell line i.e. MCF-7 were cultured as described previously (Tissue distribution study) this cell line diluted with phosphate buffer solution and injected subcutaneously into the right flank of the mice and tumor were allowed to develop. At the of 9-10 day after tumor implantation the free gemcitabine, Conventional liposomes and stealth liposomes injected into the tumor bearing mice via tail vein at $10 \mathrm{mg} / \mathrm{kg}$ 


\begin{tabular}{|c|c|c|c|c|c|c|}
\hline \multicolumn{7}{|c|}{ Table 7: Effect of Pure Gem, CL-5 and SL-5 Tumor Volume } \\
\hline \multirow{2}{*}{ Treatment } & \multicolumn{7}{|c|}{ Tumor volume $\left(\mathbf{c m}^{3}\right)$} \\
\cline { 2 - 7 } & Dose & $\mathbf{1 0}$ Day & 15 Day & $\mathbf{2 0}$ Day & $\mathbf{2 5}$ Day & $\mathbf{3 0}$ Day \\
\hline Saline solution & $10 \mathrm{mg} / \mathrm{kg}$ & $0.9 \pm 0.12$ & $1.5 \pm 0.23$ & $1.9 \pm 0.32$ & $2.5 \pm 0.1$ & $3.1 \pm 0.14$ \\
\hline $\begin{array}{c}\text { Pure } \\
\text { Gemcitabine }\end{array}$ & $10 \mathrm{mg} / \mathrm{kg}$ & $0.4 \pm 0.13$ & $0.8 \pm 0.21$ & $1.4 \pm 0.24$ & $1.7 \pm 0.12$ & $2.1 \pm 0.15$ \\
\hline CL-5 & $10 \mathrm{mg} / \mathrm{kg}$ & $0.3 \pm 0.21$ & $0.7 \pm 0.11$ & $1.1 \pm 0.2$ & $1.4 \pm 0.23$ & $1.7 \pm 0.11$ \\
\hline SL-5 & $10 \mathrm{mg} / \mathrm{kg}$ & $0.1 \pm 0.15$ & $0.3 \pm 0.12$ & $0.5 \pm 0.19$ & $0.8 \pm 0.27$ & $1 \pm 0.12$ \\
\hline
\end{tabular}

of dose. The size of the tumor and weight of each mice was monitor thereafter. the anticancer effect of gemcitabine based formulation was evaluated on the basis of the changes in tumor volume and weight at selected time interval i.e. when the tumor acquired specific size after implantation of MCF-7 cell line (at 10th day) and administration of sample itself. At the specific days interval mice were sacrificed and tumor was harvested for determine the volume of tumor, two bisecting diameter of each tumor were measured with slide caliper to determine tumor volume and calculation were performed using the formula as

$V=0.5 \times a b^{2}$

$\mathrm{a}=$ largest diameter of tumor $(\mathrm{mm})$

$\mathrm{b}=$ smallest diameter of tumor $(\mathrm{mm})$

\section{Effect of Solid Tumor Weight ${ }^{22}$}

At the end of study the weight profile of tumor treated with different form of gemcitabine as pure gemcitabine, optimized conventional and stealth liposomal formulation were comparatively evaluated by measuring tumor weight which implicate the possible anticancer activity of gemcitabine.

\section{RESULT AND DISCUSSION}

\section{Determination of Entrapment Efficiency}

Hydrophilic nature of drug unable to load inside the vesicle efficiently but the results obtained from $\mathrm{pH}$ gradient methods indicate that encapsulation of drug in the liposomes is not significantly enhanced supported by value about $47.4 \% \pm 3.2$ to $55.0 \pm 4.1 \%$. shown in Table 3 The use synthetic lipid (DPPC) with different molar conc. of cholesterol both CL and SL using $\mathrm{pH}$

\begin{tabular}{|c|c|c|c|}
\hline \multicolumn{3}{|c|}{ Table 8: Effect of Pure Gem, CL-5 and SL-5 on Tumor } \\
Weight \\
\hline Treatment & Dose & Days & $\begin{array}{c}\text { Tumor weight } \\
\text { (gm) }\end{array}$ \\
\hline Saline solution & $10 \mathrm{mg} / \mathrm{kg}$ & 30 & $6.5 \pm 0.23$ \\
\hline Pure Gemcitabine & $10 \mathrm{mg} / \mathrm{kg}$ & 30 & $5.1 \pm 0.12$ \\
\hline CL-5 & $10 \mathrm{mg} / \mathrm{kg}$ & 30 & $3.8 \pm 0.41$ \\
\hline SL-5 & $10 \mathrm{mg} / \mathrm{kg}$ & 30 & $1.7 \pm 0.31$ \\
\hline
\end{tabular}

gradient methods in which ammonium sulphate establish $\mathrm{pH}$ gradient either side of liposomes promote the encapsulation of gemcitabine inside the vesicle without back diffusion due to precipitation and formation of gel and the value obtained after study was increased as $70.2 \pm 2.12 \%$ to $75.3 \pm 4.11 \%$ hence encapsulation of gemcitabine depends on concentration of lipid and cholesterol as the concentration of cholesterol increases $\% \mathrm{EE}$ was decreases this may due to increase the rigidity of liposomal structure by the insertion of cholesterol and $\mathrm{pH}$ gradient methods as well as synthetic lipid DPPC is suitable for further study than Soya PC.

\section{Determination of Vesicle Size, Polydispersity Index (PDI) and Zeta Potential for CL}

Vesicle size of CL was reported in Table 4 and results confirm that size range of CL composed by DPPC was satisfactory $(132 \pm 0.98 \mathrm{~nm}$ to $145.5 \pm 1.33 \mathrm{~nm})$ and assure for long circulation and EPR effect at tumor site while PDI of liposomal formulation indicate for uniformity in size of vesicle (monosize). The zeta potential governs the physical stability of Liposomes. Zeta potential result of formulation depends on the nature of lipid (natural Soya PC) and synthetic lipid (DPPC, DPSE-MPEG 2K) with its molar concentration tried for initial batches reveled that Soya PC containing CL possess the zeta potential value between $-9.3 \pm 0.3 \mathrm{mv}$ to $-10.9 \pm 0.5 \mathrm{mv}$ for natural lipid whereas for synthetic lipids (DPPC) containing CL vale of zeta potential are in acceptable range i.e. $-16.3 \pm 2.2 \mathrm{mv}$ to $-32.5 \pm 0.8 \mathrm{mv}$.

\section{Determination of Vesicle Size, Polydispersity Index (PDI) and Zeta Potential for SL}

Vesicle size of stealth liposome is affected by lipid level with cholesterol from the data shown in following Table 5 and Figure 1. Which concludes that as the concentration of cholesterol increases the rigidity and size of liposomes was decreases. PDI of stealth liposomes suggest that size distribution are uniform and monosize for all vesicles without aggregation. Figure 2 to 5 depicted vesicle size distribution profile of both conventional \& stealth liposomal formulation. Similarly for SL synthetic lipids such as DPPC, DSPE-MPEG 2K was incorporated into the liposomes and zeta potential becomes more negative due to PEG residue i.e.- $25.3 \pm 1.7 \mathrm{mv}$ 


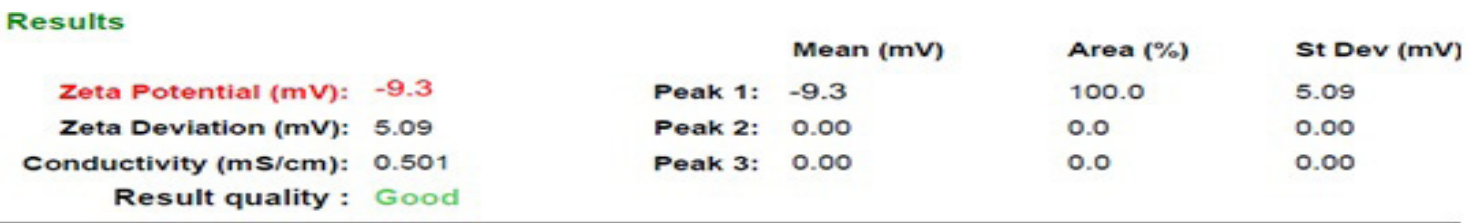

Zeta Potential Distribution

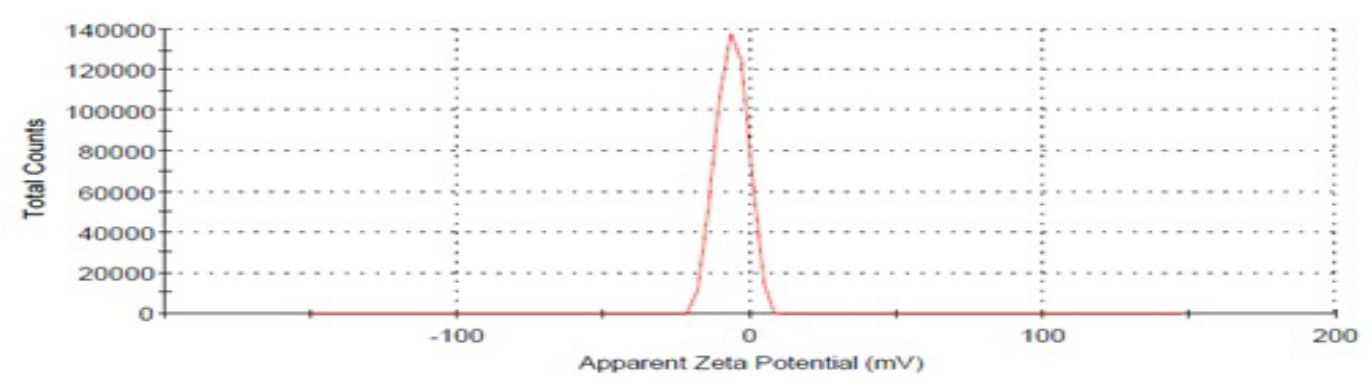

Figure 6: Zeta Potential of CL-1

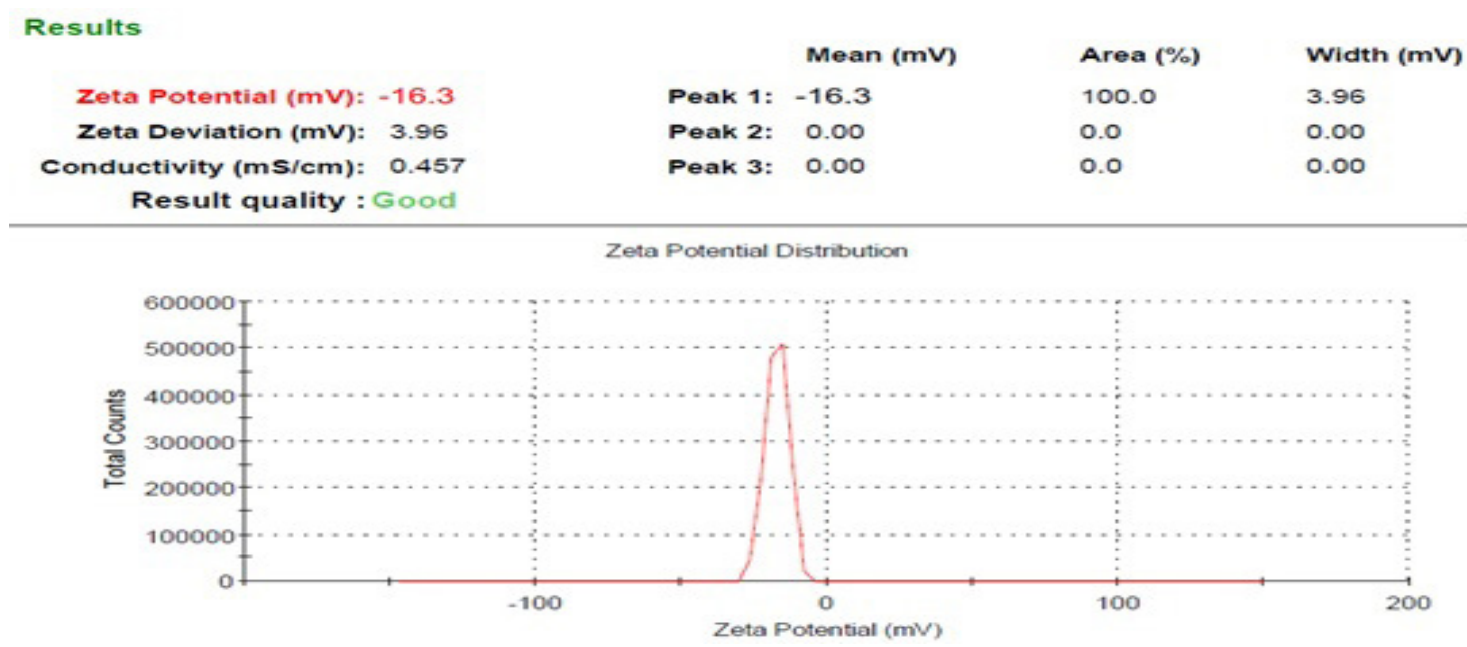

Figure 7: Zeta Potential of CL-4

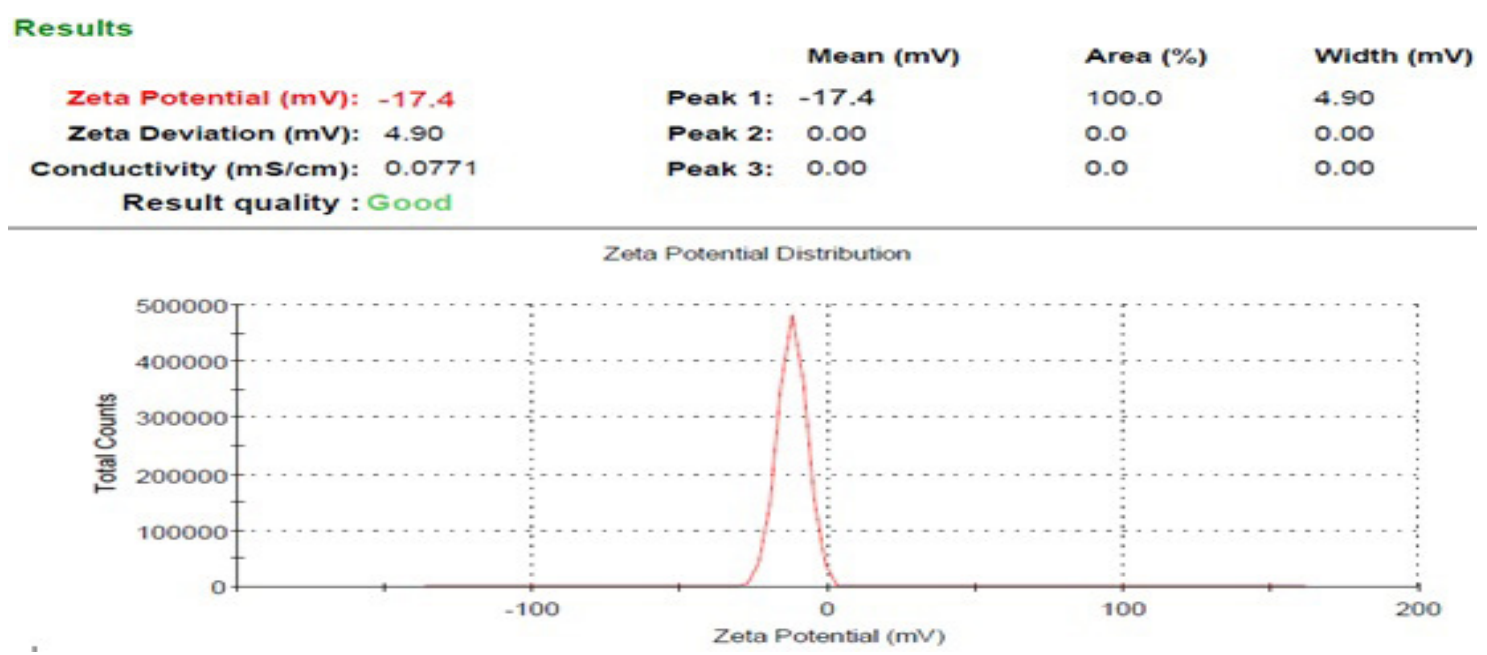

Figure 8: Zeta Potential of SL-1 
Menuma

\begin{tabular}{|c|c|c|c|c|c|}
\hline & & & Mast anti & Aran thit & Minin tam \\
\hline 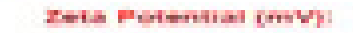 & $2 \pi$ & Feall 11 & $\sin x$ & IHB 8 & I m \\
\hline Derdustiqity imtamb! & anpit & Pariti: & ang & 00 & ning \\
\hline
\end{tabular}

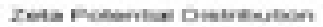

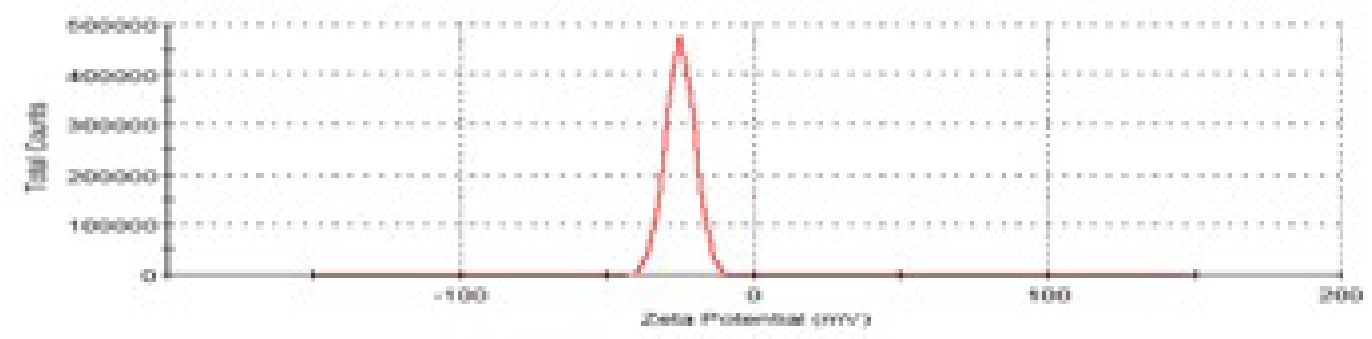

Hewer inmonts

Figure 9: Zeta Potential of SL-4

Zeta Potential of Conventional \& Stealth liposomes

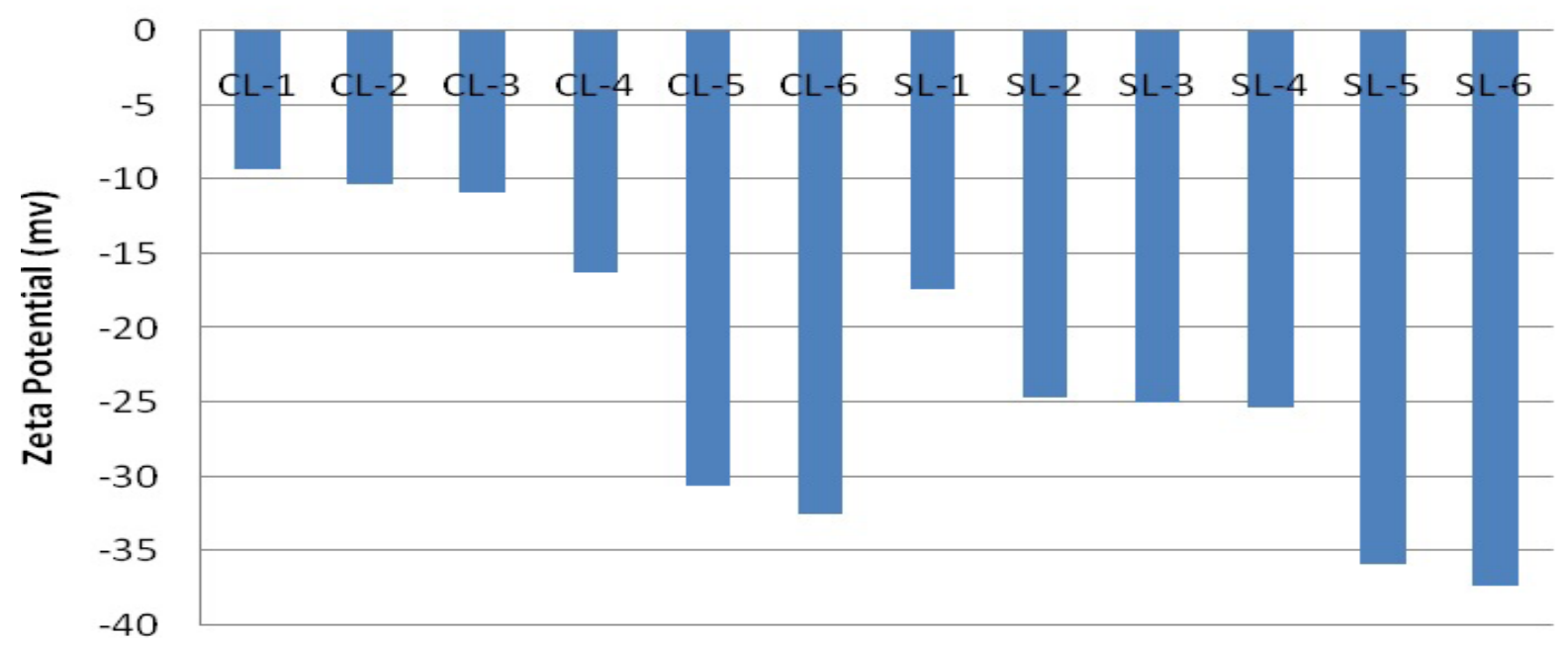

Figure 10: Comparative Zeta Potential of CL and SL

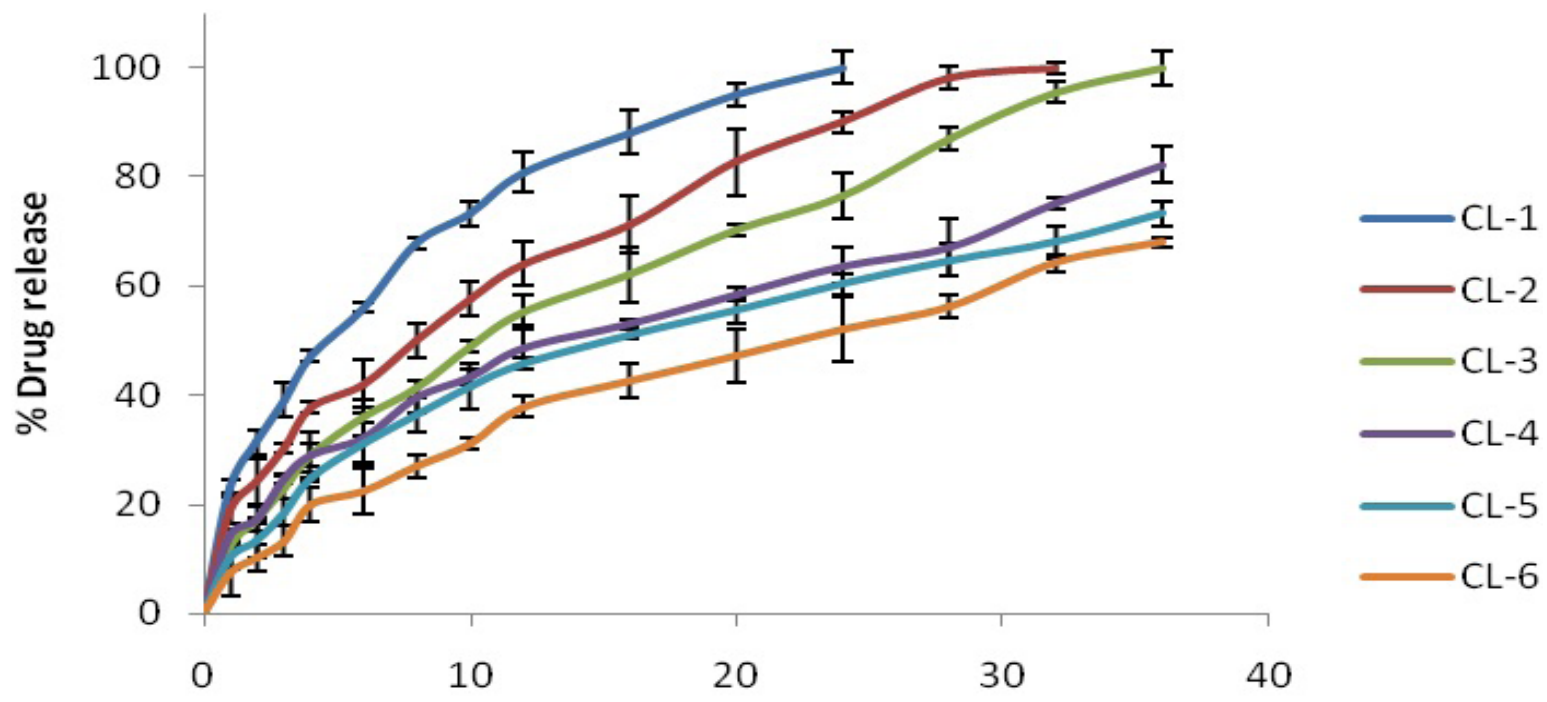

Time in Hrs.

Figure 11: In vitro release profile of CL-1 to CL-6 


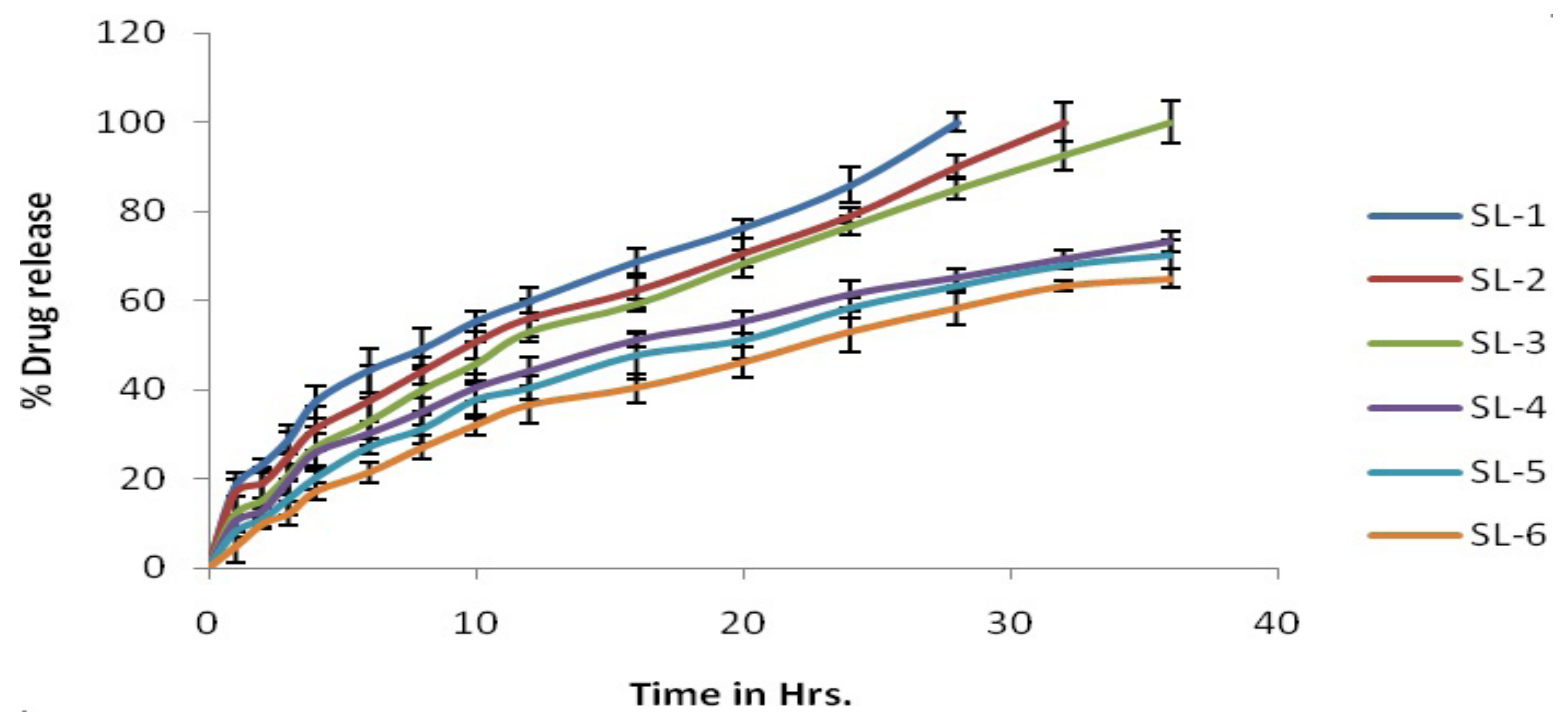

Figure 12: In-vitro release profile of SL-1 to SL-6

Pure gemcitabine $\quad$ Conventional liposomes $\quad$ Stealth liposomes

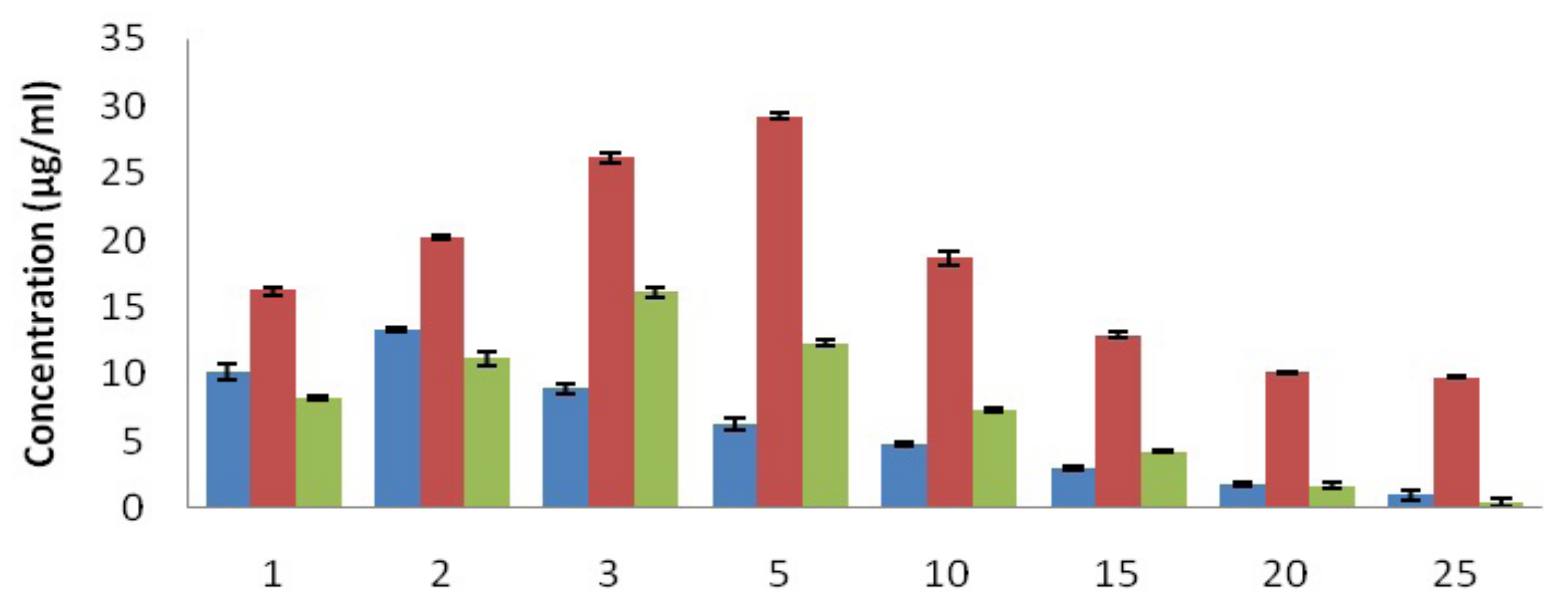

Time in hrs

Figure 13: Biodistribution of pure gem, CL-5, and SL-5 in Spleen

to $-37.1 \pm 0.8 \mathrm{mv}$ that indicates electrostatic repulsion between two particles. DLVO theory states that electric double layer repulsion will stabilize liposomal formulation and aggregation is not expected to take place, due to the highly negative charge of particles. Zeta potential of both types of formulation are shown in Figures 6 to 9 whiles as comparatively shown in Figure 10.

\section{Determination of Zeta Potential}

\section{In-vitro Release Study (CL and SL)}

The conventional liposomes released about $100 \%$ gemcitabine within 24, 32 and 36 hrs. respectively for the batches as CL-1,CL-2,CL-3 are shown in Figure 11 Therefore it concluded that natural lipid like soya PC is not effective retardant for gemcitabine release. When the liposomes contains the synthetic lipid (DPPC) release rate was decreased and about $82.23 \pm 3.2,73.23$ \pm 2.1 and $68 \pm 1$ for CL-4, CL-5 and CL- 6 respectively indicate that release rate highly affected by concentration of lipid and cholesterol at higher concentration of DPPC:DSPE-MPEG 2-K :Cholesterol (7:0.3:3) release rate was decreased upto $68 \%$ after $36 \mathrm{hrs}$. Hence based on release profile CL- 5 has been optimized formulation for further studies due to prolong release rate for $36 \mathrm{hrs}$. Stealth liposomes composed with different molar concentration of Soya PC: DSPE-MPEG 2K as 5:0.1, 6:0.2 and 7:0.3 for the batches SL-1, SL-2 and SL-3 release of gemcitabine is almost $100 \%$ within 28,32 , and 36 hrs. As shown in Figure 12 burst effect was observed in the gemcitabine release profile of all liposomal formulation during first $2 \mathrm{hrs}$. This finding was probably due to rapid desorption of gemcitabine from liposomal bilayers. Dissolution profile of stealth liposomes i.e. 


\section{Pure gemcitabine $\quad$ Conventional liposomes $\quad$ Stealth liposomes}

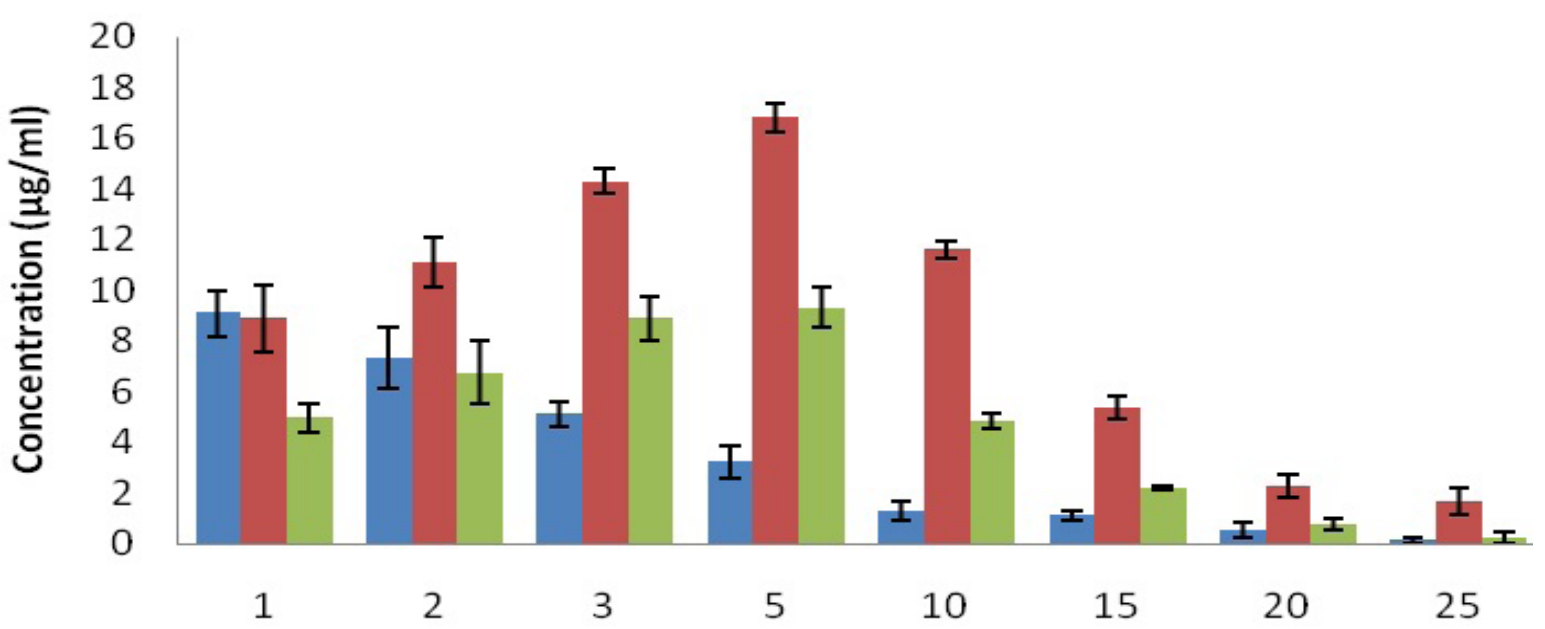

Time in hrs.

Figure 14: Biodistribution of pure gem, CL-5, and SL-5 in Liver

Pure gemcitabine $\quad$ Conventional liposomes $\square$ Stealth liposomes

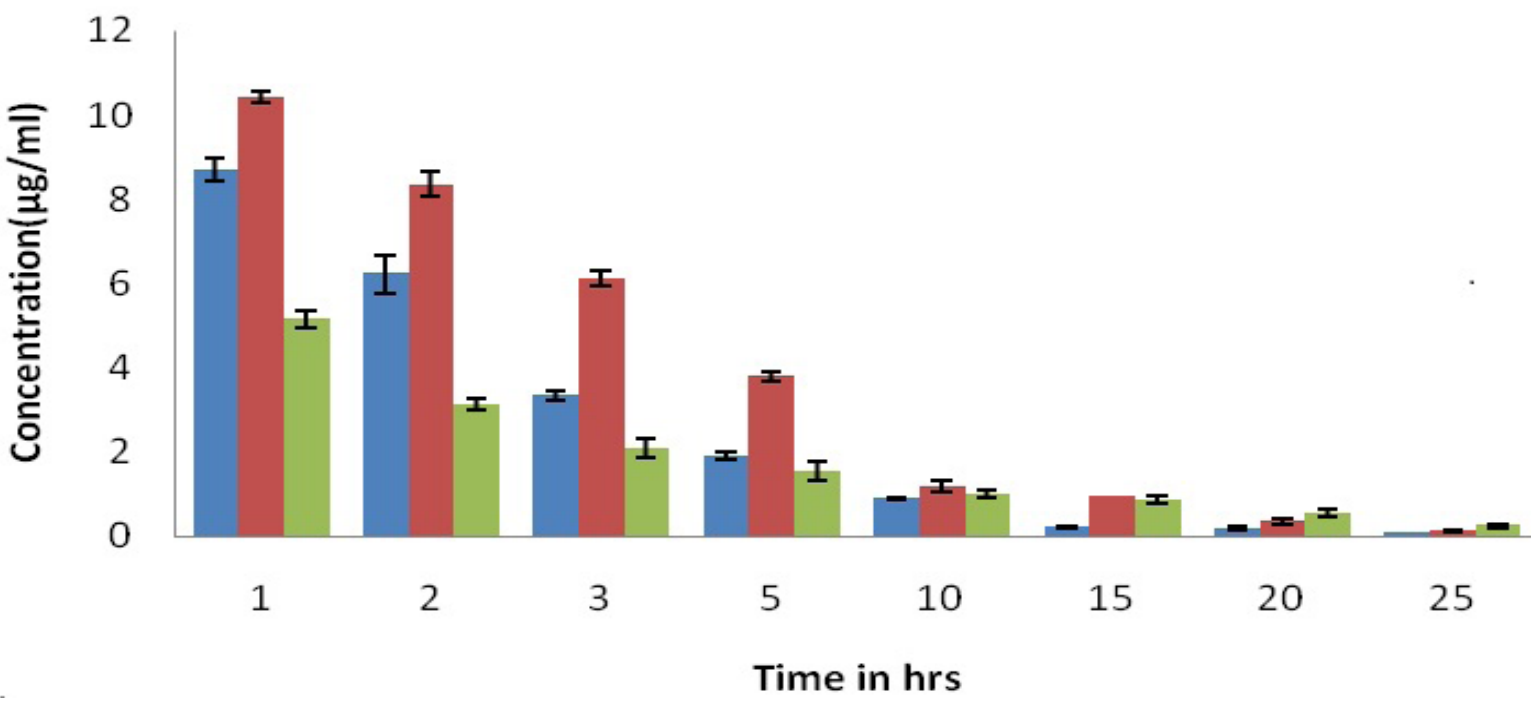

Figure 15: Biodistribution of pure gem, CL-5, and SL-5 in Lungs

SL-4, SL-5 and SL-6 composed by synthetic lipid with different molar concentration of DPPC: Cholesterol : DSPE-MPEG 2K as 5:1:0.3, 6:2:0.2 and 7:3:0.3 evaluated comparatively and release rate was obtained $73 .{ }^{13}$ $\pm 2.3 \%, 70.23 \pm 3.2 \%$ and $65 \pm 2 \%$ respectively the release rate of gemcitabine from the vesicle is sustained or controlled manner upto $36 \mathrm{hrs}$. for stealth liposomes all batches give the assurance for prolong release of content with improvement of circulation half life of gemcitabine for achieving of the maximum therapeutic drug concentration at tumor site with less toxic effect and SL-5 were optimized due to release rate of gemcitabine in controlled manner for longer period of time.

Pharmacokinetic study: To assess the pharmacokinetic behavior of gemcitabine loaded optimized CL and SL with dose as $10 \mathrm{mg} / \mathrm{kg}$ was administered by I.V. route to the MCF-7 tumor bearing animal like mice and plasma profile of free Gemcitabine CL-5 and SL-5 are shown in Figure 18 and pharmacokinetic parameters presented in Table 6 from this result the free gemcitabine solution was quickly removed from the circulation at 1 hrs. after I.V. injection with negligible blood concentration showing biphasic pattern with rapid elimination phase with half life $\left(t_{1 / 2}\right) 1.33 \pm 0.27$ hrs. The volume of distribution $(\mathrm{Vd}) 5.24 \pm 0.29 \mathrm{ml}$ was very low ,further the value of AUC,AUMC,MRT of free gemcitabine significantly lower then CL-5 and SL-5 suggested by ANOVA $(\mathrm{p}<0.005)$. The pharmacokinetic of CL- 5 were studied and the value of $\mathrm{t}_{1 / 2}$, MRT, AUC was $5.28 \pm 1.62 \mathrm{hrs}, 4.15 \pm 1.0 \mathrm{hrs}$ and $15.22 \pm 0.02$ $\mu \mathrm{g} / \mathrm{ml} \mathrm{h}$ respectively and from this it was clear that in vivo circulation behavior of CL- 5 was significantly much 
- Pure gemcitabine $\quad$ Conventional liposomes $\square$ Stealth liposomes

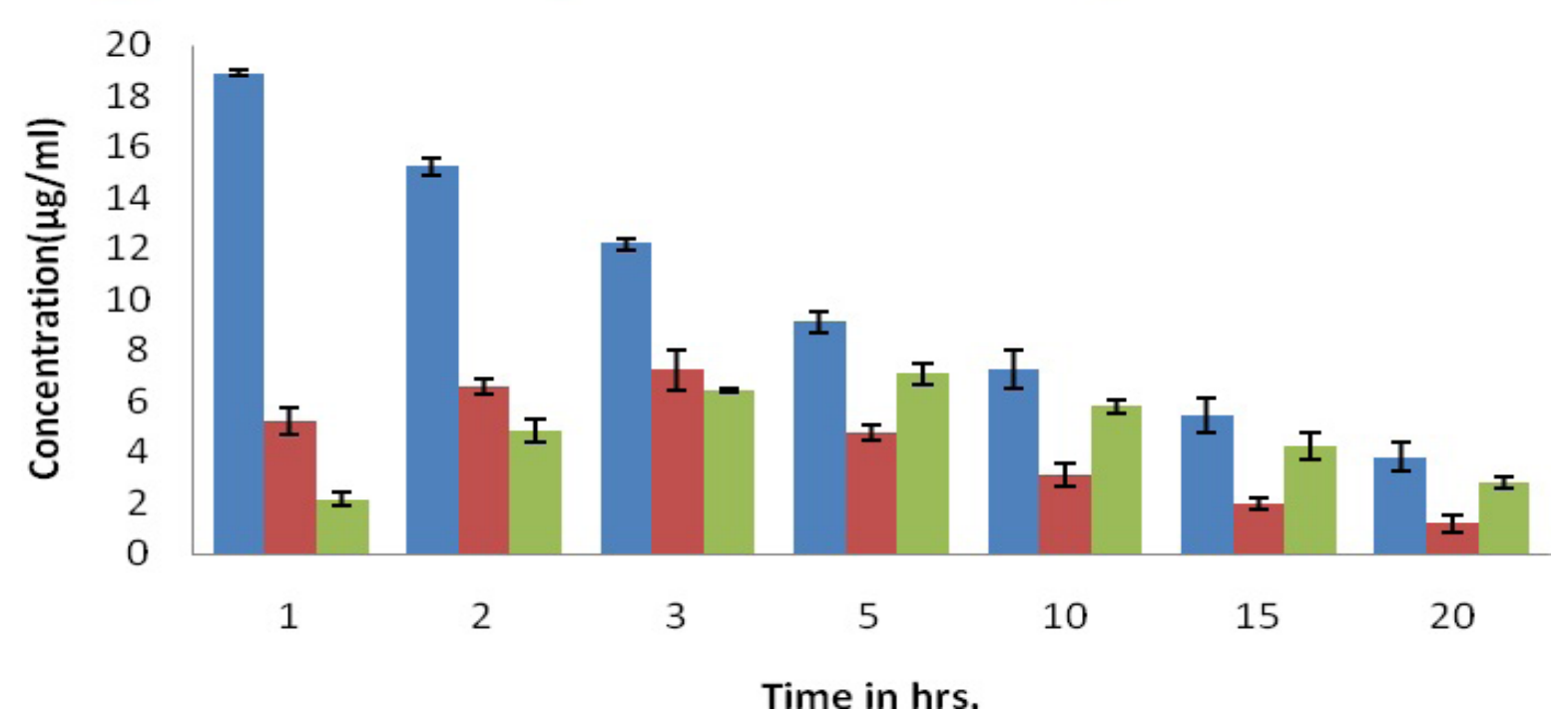

Figure 16: Biodistribution of pure gem, CL-5, and SL-5 in Kidney घure gemcitabine $\quad$ Conventional liposomes $\quad$ Stealth liposomes

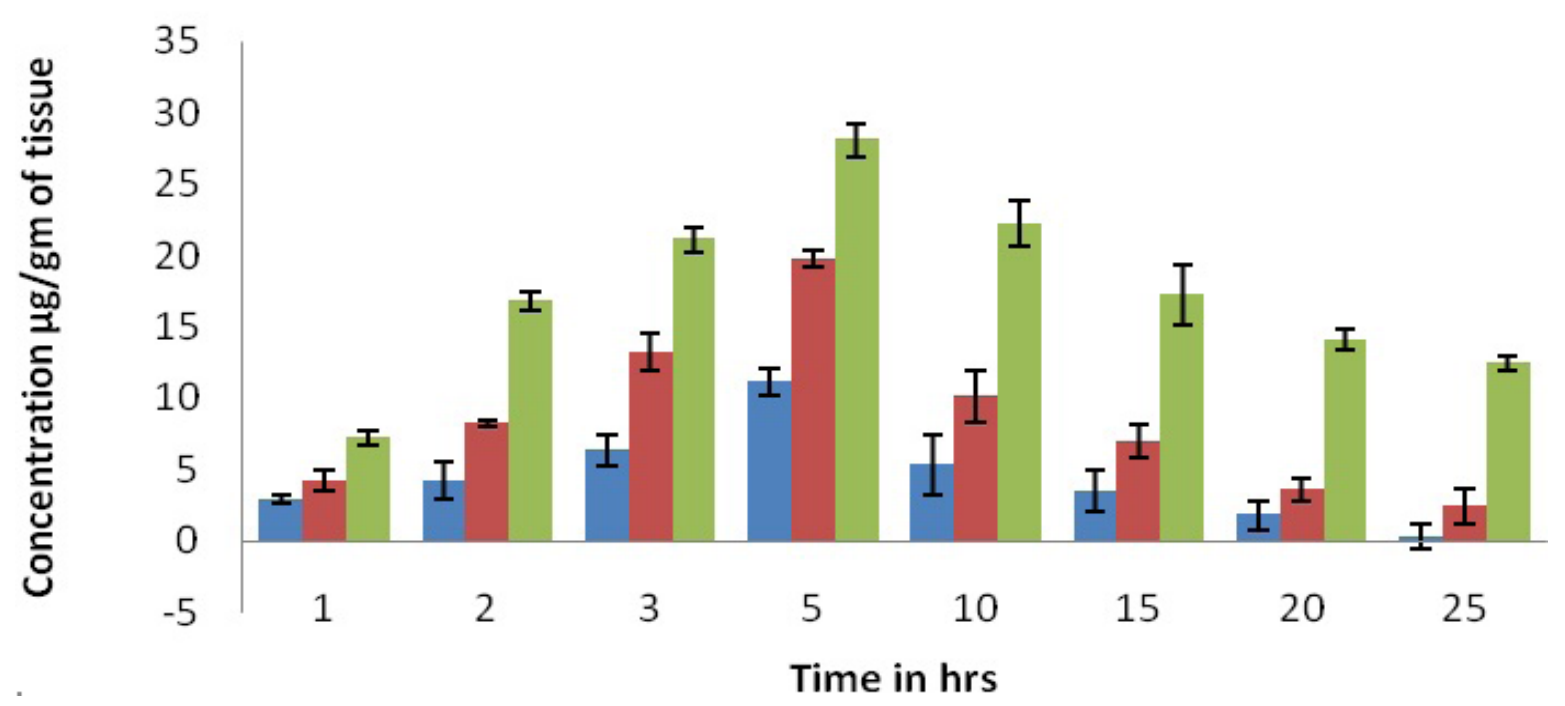

Figure 17: Biodistribution of pure gem, CL-5, and SL-5 in Tumor

better than pure (free) gemcitabine solution. When the SL-5 was compared with pure gemcitabine, CL-5 based on pharmacokinetic profile after I.V. injection to animal model and the AUC, AUMC, MRT and $\mathrm{t}_{1 / 2}$ significantly greater than pure drug and CL-5. In contrast blood level of SL remained high for long period of time than CL-5. The area under curve (AUC) of SL was $19.37 \pm 0.09 \mu \mathrm{g}$ $/ \mathrm{ml}$ h much higher than the CL-5 as $15.22 \pm 0.02 \mu \mathrm{g} /$ $\mathrm{ml} \mathrm{h}$ and very less for free drug $8.37 \pm 0.04 \mu \mathrm{g} / \mathrm{ml} \mathrm{h}$ The small volume of distribution of SL-5 as $2.4 \pm 0.24$ $\mathrm{ml}$ and for the CL-5 was $3.1 \pm 0.17 \mathrm{ml}$ conform that SL-5 restricted to the systemic circulation whereas the pure gemcitabine have a large volume of distribution $5.24 \pm 0.29 \mathrm{ml}$ means distribution of pure gemcitabine in the various tissue rather than blood. The $t_{1 / 2}$ of SL-5 increased 8.6 fold and MRT 12 fold increased than CL-5 proves that prolong circulation half-life of SL-5 reduce the chances of rapid uptake by element of Mononuclear Phagocytic system (MPS) and plasma opsonin due to steric barrier produce by incorporation of PEG residue on the vesicle which make liposomal formulation as more hydrophilic and physiologically stable.

Tissue Distribution Study: The tissue distribution of pure drug, CL-5 and SL-5 was examined by inoculating human breast tumor cell culture (MCF-7) into the mice.

Biodistribution profile of Gemcitabine in Spleen: To evaluate real potency of optimized stealth liposomes (SL-5) against certain solid tumor by measuring it distribution in various RES rich organs such as spleen and result are shown in Figure 13. 


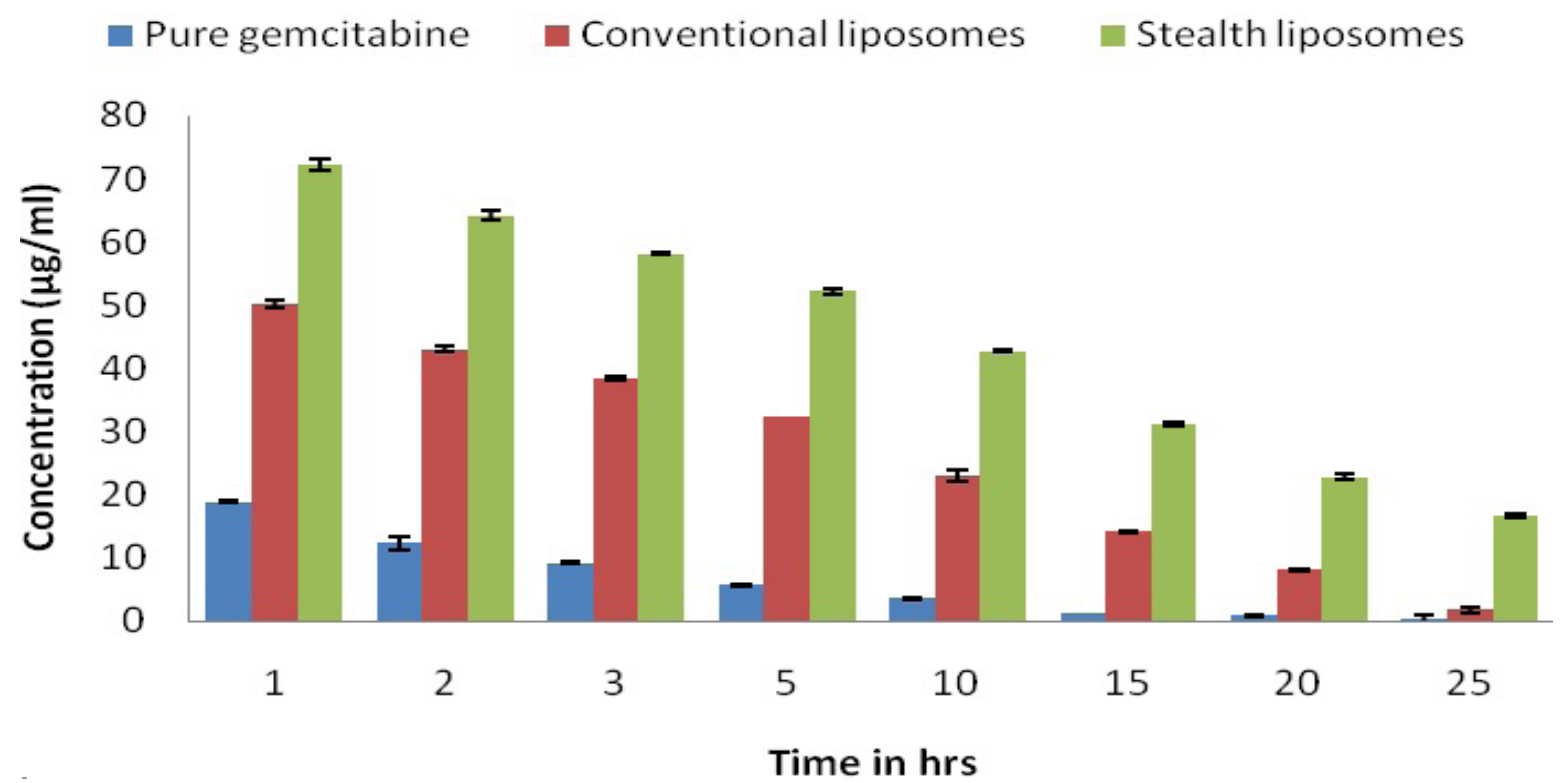

Figure 18: Biodistribution of pure gem, CL-5, and SL-5 in Blood
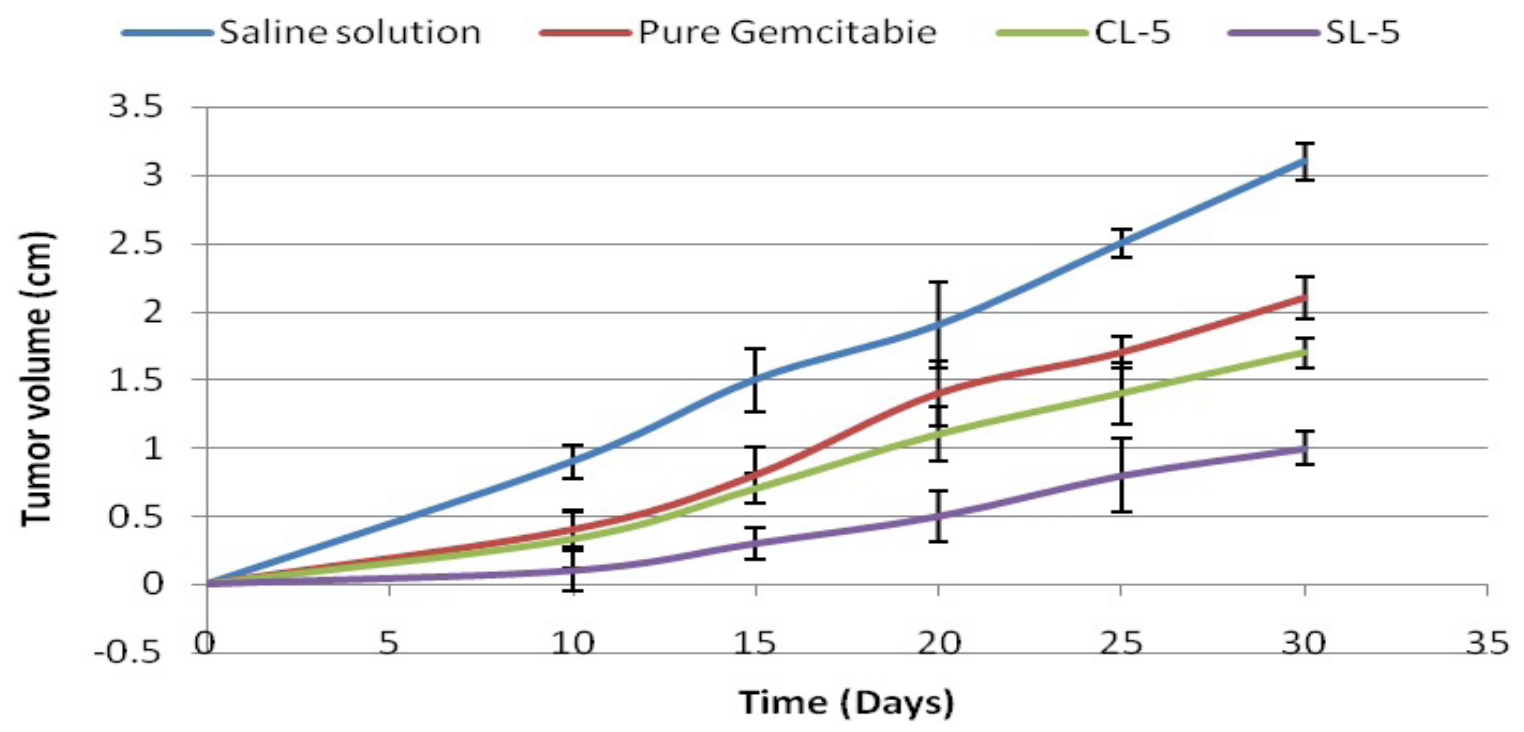

Figure 19: Effect of pure gem, CL-5, and SL-5 on Tumor Volume

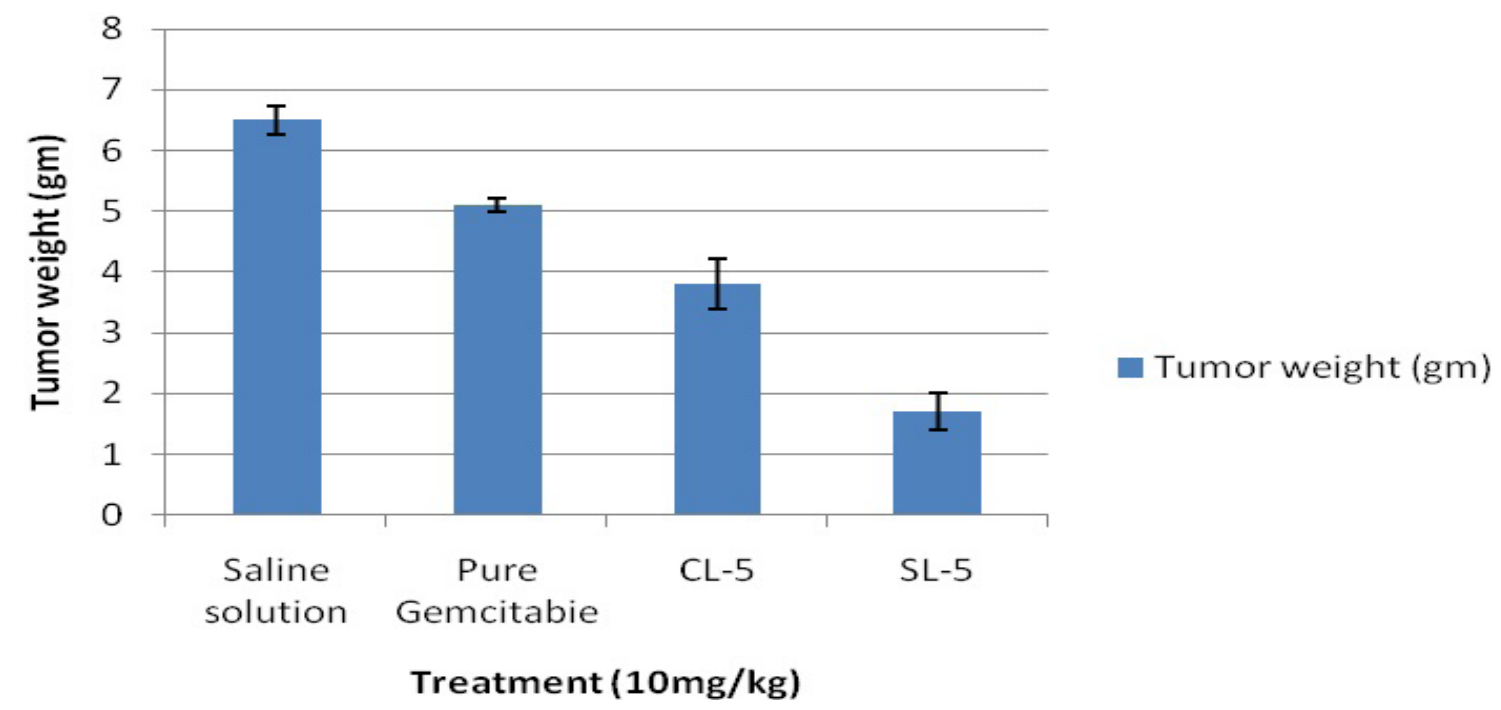

Figure 20: Effect of pure gem, CL-5, and SL-5 on Tumor Weight 
In case of pure gemcitabine maximum concentration achieved in spleen was $(13.32 \pm 0.21 \mu \mathrm{g} / \mathrm{gm}$ of spleen $)$ after 2 hrs. i.e. Initial phase and decline rapidly and almost negligible at $24 \mathrm{hrs}$. $(0.98 \pm 0.4 \mu \mathrm{g} / \mathrm{gm}$ of spleen). However conventional liposome's (CL-5) showing massive and prolonged presence in spleen with rapid uptake due to lipid and cholesterol which is unable to prevent accumulation of liposomes in the spleen. Spleen is a major RES enrich organs so far conventional liposomes quickly cleared by blood pool and enter in the spleen and the maximum concentration of CL- 5 in spleen was ( $29.23 \pm 0.23 \mu \mathrm{g} / \mathrm{gm}$ of spleen) observed after $5 \mathrm{hrs}$. and detected after 24 hrs. with higher concentration ( $9.76 \pm 0.16 \mu \mathrm{g} / \mathrm{gm})$. The distribution pattern of stealth liposomes (SL-5) to the spleen was drastically altered due to steric stabilization by inclusion of PEG grafting avoids the uptake by spleen and only $(16.11 \pm 0.4 \mu \mathrm{g} /$ gm of spleen) concentration was found at $3 \mathrm{hrs}$. and almost disappeared after $24 \mathrm{hrs}$.

Biodistribution profile of Gemcitabine in Liver: The high concentration of conventional liposomes (CL5) obtained by the liver $(16.8 \pm 0.57 \mu \mathrm{g} / \mathrm{gm}$ of liver at 5 hrs.), followed by pure gemcitabine administration ( 9.1 $\pm 0.9 \mu \mathrm{g} / \mathrm{gm}$ of liver at $1 \mathrm{hrs}$.) and is also the result of an extensive uptake, which is a reflection of its higher value. This finding can be explained by the high affinity binding of conventional liposomes to liver. The reduction of the CL-5 uptake by the liver at $15 \mathrm{~h}$ and pure gemcitabine $4 \mathrm{~h}$, respectively, may be due to the saturation of the mononuclear phagocytic system. After these time periods, elimination over the entire experiment time period. However stealth liposomes (SL-5) was finded in liver with maximum concentration $(10 \pm 0.21$ $\mu \mathrm{g} / \mathrm{gm})$ at $5 \mathrm{hrs}$ study and almost removed from liver after 20 hrs. . Biodistribution profile of gemcitabine in different forms in liver are reported in Figure 14.

Biodistribution of Gemcitabine in Lung: Specificity of liposomal formulation along with pure drug towards lungs was negligible and maximum drug appeared within $1 \mathrm{hrs}$. and rapid decline phase has been started later time period CL-5 shows around $(10.43 \pm 0.12 \mu \mathrm{g} / \mathrm{gm})$ concentration in lungs slightly higher than pure drug (8.7 $\pm 0.28 \mu \mathrm{g} / \mathrm{gm})$ and SL-5 $(5.15 \pm 0.2 \mu \mathrm{g} / \mathrm{gm}$.) All the formulation diapered from lungs after $24 \mathrm{hrs}$ study are indicated in Figure 15.

Biodistribution of Gemcitabine in Kidney: In fact in the case of free gemcitabine, it was interesting to note its rapid appearance in kidney after 1-2 hrs. and concentration observed as (18.9 $\pm 0.12 \mu \mathrm{g} / \mathrm{gm}$ of kidney) while as significant decreased in conventional liposomes with concentration as $(7.21 \pm 0.78 \mu \mathrm{g} / \mathrm{gm}$ of kidney at $3 \mathrm{hrs}$.) and stealth liposomes $(6.42 \pm 0.1 \mu \mathrm{g} / \mathrm{gm}$ of kidney). shown in Figure 16. This phenomenon is probably due to metabolism of gemcitabine and rapid elimination through urine but entrapment of drug inside the vesicle gives the protection against metabolism with little appearance in kidney. Almost all the formulation were detected in kidney prior to $24 \mathrm{hrs}$. study.

Biodistribution of Gemcitabine in Tumor: As the time increased, the accumulation in tumor was found to increase, reaching a peak at 24 hours; after 48 hours, the concentration in tumor was decreased. The PEG grafting on stealth liposomal formulation most promising to avoid uptake of gemcitabine in RES rich organs and enhance the circulation half life of gemcitabine and smaller vesicular size promote Enhanced permeability retention (EPR) effect for maximum localization of drug in tumor cells around $(12.45 \pm 0.5 \mu \mathrm{g} / \mathrm{gm})$ concentration of gemcitabine achieved after $24 \mathrm{hrs}$ while as CL-5 shows as only $(2.4 \pm 1.2 \mu \mathrm{g} / \mathrm{gm})$ concentration and pure drug was $(0.3 \pm 0.87 \mu \mathrm{g} / \mathrm{gm})$ appeared at tumor site it may due to distribution of pure drug and CL-5 towards various organs rather than tumor.

\section{Biodistribution of Gemcitabine in Blood (Plasma):}

In particular, by observing the distribution in mice of gemcitabine in it was found that gemcitabine in free form rapidly appeared in blood within $1 \mathrm{hrs}$ after I.V.injection of tumor bearing mice with maximum concentration as $(18.87 \pm 0.1 \mu \mathrm{g} / \mathrm{ml})$ shown by Figure 18 but as the time increase the decline phase was started it might due to rapid metabolism of drug in blood and form inactive compound. When gemcitabine encapsulated in conventional liposomes (CL-5) the plasma level after $1 \mathrm{hrs}$. Was found to be $(50.23 \pm 0.7 \mu \mathrm{g} / \mathrm{ml})$ i.e. around 2.8 fold increased compare with free drug and further it remain into the blood after $24 \mathrm{hrs}$. As expected drug incorporated in stealth liposomes (SL-5) liposomes showed a remarkable enhancement of blood concentration than free drug and conventional liposomes and was still present in circulation after 24 hrs. $(16.66 \pm 0.3 \mu \mathrm{g} / \mathrm{ml})$ i.e around 16 fold higher than the CL-5.

Tumor localization of liposomes: Figure 17 shows that distribution of gemcitabine in tumor at various time intervals after injection. The accumulation of gemcitabine in tumor was decreased when the drug was entrapped into the CL-5 and free form. However a marked increase in accumulation in tumor was found for SL-5 supported by the concentration as $(18 \mu \mathrm{g} / \mathrm{gm})$ after 24 hrs. Smaller size of SL-5 and steric stabilization by PEG improve enhanced permeability and retention effect (EPR) by promoting SL-5 into tumor interstitial space and extravasation.

\section{In vivo Antitumor Activity}

Effect on Tumor Volume: Mice bearing MCF-7 tumor were injected with free gemcitabine, conventional lipo- 
some's and stealth liposome's with $10 \mathrm{mg} / \mathrm{kg}$ dose, mice were given saline solution as control. Tumor growth inhibition curve in terms of mean tumor size $(\mathrm{mm})$ were presented in Figure 19 and Table 7.

The pure gemcitabine is not much effective for prevention of tumor growth compare with conventional liposomes (CL-5) treatment with CL-5 displayed strong tumor inhibition with tumor volume as $1.7 \pm 0.11 \mathrm{~cm}^{3}$ while as pure gemcitabine treated tumor volume was 2.1 $\pm 0.15 \mathrm{~cm}^{3}$. When the tumor treated with stealth liposomes (SL-5) provide cellular advantages in terms of tumor accumulation of gemcitabine due to PEG coating. In this case tumor cell distribution of SL-5 could be combined with fusogenic property of PEG able to induce interaction with tumor cell membrane and consequently to promote an efficient delivery of drug which reduce the tumor volume as $1 \pm 0.12 \mathrm{~cm}^{3}$ after 30 days study significantly lower than CL-5 and free drug. This feature is particular importance for suppression of tumor growth with increased local concentration at tumor site via EPR effect.

Effect on Tumor Weight: As seen in figure 20. Effect of formulation on tumor weight it clearly indicate that tumor weight was about 3 times less than $(1.7 \pm 0.31$ $\mathrm{gm})$ than control group as $(6.5 \pm 0.23 \mathrm{gm})$ hence growth of tumor were retarded upto 30 days of study. Similarly the effect of pure gemcitabine and optimized conven- tional liposomal formulation on tumor weight was (5.1 $\pm 0.12 \mathrm{gm}$ to $3.8 \pm 0.41 \mathrm{gm}$ ) respectively hence above comparison with respect to tumor weight was helpful for stealth liposomal formulation is effective against solid tumor with maximum cytotoxic effect. The results obtained through this study were reported in Table 8 .

\section{CONCLUSION}

Stealth liposomes of gemcitabine was successfully prepared by the $\mathrm{pH}$ gradient technique by using synthetic lipid which successfully conjugated with the gemcitabine. The optimization of conventional and stealth liposomal formulation was done based on particle size and entrapment efficiency and release profile. Tissue distribution study of optimized CL-5 compared with SL-5 using tumor model and SL-5 showed promising results than CL- 5 in terms of prolong circulation half life and less RES uptake. Hence it concludes that stealth liposomal drug delivery system is future for anticancer drug for target specificity.

\section{ACKNOWLEDGEMENTS}

The authors are thankful to Lipoid GmbH, Ludwigshafen Germany, for providing the gift samples of phospholipids.

\section{SUMMARY}

- Gemcitabine is a novel anticancer drug clinically proven for various cancer like colon,breast,prostate etc.but in available dosage form of gemcitabine having some limitation due to its unwanted effect like bone marrow suppression so limited in use.

- Stealth liposomal drug delivery system is novel approach for treatment of solid tumor due to its Enhanced Permeability and Retention Effect (EPR effect) and target specificity for prolong circulation in biological system.

- Hence present investigation is tried to overcome certain limitation for cancer therapy and benefits as

- To avoids the RES clearance of gemcitabine by various organs and enhance tumor accumulation by prolong circulation in blood.

- To enhance therapeutics outcomes of gemcitabine for various tumours due to its size (nano range) and via EPR effect.

- To avoids unwanted toxicity of gemcitabine mentioned earlier through encapsulation in vesicles.

- Above statement are eventually proven by formulation, characterization and in vivo study by using certain animal including Toxicity profile, pharmacokinetics behaviour, cell line study using certain tumor models.

\section{About Authors}

Ganesh Sheshrao Bangale: Presently working as Assistant Prof. in the Department of Pharmaceutics, Government College of Pharmacy, Amravati, Maharashtra he has 25 nos. of journal paper; 2 nos. of book chapter; His area of research is nanotechnology like formulation \& charecterization of nanoparticle, liposomes, dendrimers
Gajanan Vishwambharao Shinde: Working as Asstt. Prof. and PhD scholar of Department of Pharmaceutics, Parul Institute of Pharmacy, Baroda,Gujarat He has 30 nos. of journal paper; 3 books in press; 3 invited talk; $\mathrm{He}$ is consultant of BDR pharma.He is also inchrge of nanotechnology division in Parul university, Baroda. 


\section{REFERENCES}

1. Kasper DL, Fauci AS, Lonso DL. Harrison's Principles of Internal Medicine, $16^{\text {th }}$ Edn, McGraw-Hill; 2005. 435-515.

2. Charles G., Robert S. Modern Pharmacology with Clinical Applications, $5^{\text {th }}$ Edn, Lippincott Williams \& Wilkins; 1997. 509-676,

3. National Comprehensive Cancer Network, February 2013 http://www.nccn. com/understanding-cancer/1042-liquid-versus-solid-tumors.html

4. National Cancer Institute, September 2009, http://www.cancer.gov/ cancertopics/understandingcancer/cancer

5. Theresa M. Allen. Pharmacokinetics of long-circulating liposomes, Advanced Drug Delivery Reviews 1995; 16: 267-84.

6. Amarnath Sharma Liposomes in drug delivery: progress and limitations, International Journal of Pharmaceutics 1997; 154: 123-40.

7. Maria Laura Immordino, Paola Brusa. Preparation, characterization, cytotoxicity and pharmacokinetics of liposomes containing lipophilic gemcitabine prodrugs. Journal of Controlled Release 2004; 100: 331-46.

8. Gemcitabine (Systemic). [Online]. 2005 [cited 2006 May 6]; Available from: http://www.nlm.nih.gov/medlineplus/druginfo/uspdi/203038.html\#SXX08

9. Martin C. Woodle Sterically stabilized liposomes, Biochimica et Biophvica Acta. 1992; 111(3): 171-99.

10. Brandl M. Liposomes as drug carriers: a technological approach. Biotechnol Annu Rev. 2001; 7: 59-85.

11. Massing U, Fuxius S. Liposomal formulations of anticancer drugs: selectivity and effectiveness. Drug Resist Update 2000; 3: 171-7.

12. Mali Deepak, Formulation and Characterization of Tamoxifen Loaded Stealth Liposomes for Breast Cancer. IJDDR. Jan-Mar 2013; 5(1): 271-8.

13. Patel RP, Patel H, Baria AH. Formulation and Evaluation of Liposomes of Ketoconazole. Int. J. Drug Del. Technol. 2009; 1(1): 16-23.
14. Kumar A, Badde S, Kamble R, Pokharkar VB. Development and characterization of liposomal drug delivery system for Nimesulide. Int. J. Pharmacy Pharm. Sci. 2010; 2(4): 975-1491.

15. Yasmin Begum M. Preparation, Characterization and In vitro Release Study of Flurbiprofen Loaded Stealth Liposomes ChemSci Trans. 2012; 1(1): 201-9.

16. Ganesh S.Bangale et al. Formulation and In vitro Cytotoxicity Studies of Stealth Liposomes. Inventi Rapid: NDDS 2014; 3: 1-14

17. Christian Celia, Natalia Malara et al. Liposomal delivery improves the growth-inhibitory and apoptotic activity of low doses of gemcitabine in multiple myeloma cancer cells. Nanomedicine: Nanotechnology, Biology, and Medicine 2008; 4: 155-66.

18. Arulsudar N, Subramanian. Preparation, Characterization, and Biodistribution Study of Technetium-99m -Labeled Leuprolide Acetate-Loaded Liposomes in Ehrlich Ascites Tumor-Bearing Mice. AAPS Pharm Sci. 2004; 6(1): 1-12.

19. Tatsuhiro Ishida et al. Accelerated clearance of a second injection of PEGylated liposomes in mice. International Journal of Pharmaceutics 2003; 255: 167-74.

20. Amol Pitrubhakta B. Design, Development and Characterization of PEGylated Liposomes of Gemcitabine Hydrochloride. Der Pharmacia Lettre. 2012; 4(1): 314-29.

21. Sake Unezaki, Kauzo Maruyama et al. Enhanced tumor targeting \& improved anyitumor activity of doxorubicin by long circulating liposomes containing amphipathic PEG. International J. of Pharmaceutics. 1995;126: 41-8.

22. Olson F, Mayhew E. Characterization, toxicity and therapeutic efficacy of adriamycin encapsulated in liposomes. Eur. J. Cancer Clin. Oncol. 1982;18: 167-76. 